\title{
Mesophyll conductance constrains photosynthesis in three common sclerophyllous species in Central Chile
}

\author{
Carla E Brito ${ }^{1}$, Horacio E Bown ${ }^{1 *}$, Juan-Pablo Fuentes ${ }^{1}$, Nicolás Franck ${ }^{2}$ and Jorge F Perez-Quezada ${ }^{3}$
}

\begin{abstract}
Background: Quillaja saponaria Mol., Cryptocarya alba Mol. Looser, and Lithraea caustica Molina Hook et Arn., are common sclerophyllous species in Mediterranean Central Chile. Mesophyll conductance, $g_{m}$, may strongly limit photosynthesis in these semiarid environments.

Results: Simultaneous measurements of gas exchange and chlorophyll fluorescence were carried out in 45 nursery plants from these species to determine diffusional and biochemical limitations to photosynthesis. Values of stomatal conductance, $g_{s}$, were greater than those of mesophyll conductance, $g_{m}$, while their ratio $\left(g_{m} / g_{s}\right)$ was not influenced by species being on average 0.47 . Relative limitations posed by mesophyll conductance to photosynthesis, $L_{m \prime}(0.40 \pm 0.02)$ were high compared to those imposed by stomata, $L_{s}(0.07 \pm 0.01)$. The average $\mathrm{CO}_{2}$ concentration in the intercellular air spaces $\left(C_{\mathrm{i}}\right)$ was $32 \mu \mathrm{mol} \mathrm{mol}{ }^{-1}$ lower than in the atmosphere $\left(C_{\mathrm{a}}\right)$, while the average $\mathrm{CO}_{2}$ concentration in the chloroplasts $\left(C_{\mathrm{c}}\right)$ was $131 \mu \mathrm{mol} \mathrm{mol}{ }^{-1}$ lower than $C_{\mathrm{i}}$ independent of species. Maximal rates of Rubisco carboxylation, $V_{\text {cmax }}$ and maximal electron transport rates driving regeneration of RuBP, $J_{\text {max }}$ ranged from 13 to $66 \mu \mathrm{mol} \mathrm{CO} \mathrm{Cm}^{-2} \mathrm{~s}^{-1}$ and from 33 to $148 \mu \mathrm{mol}$ electrons $\mathrm{m}^{-2} \mathrm{~s}^{-1}$, respectively, and compare well to averages for $\mathrm{C}_{3}$ plants.
\end{abstract}

Conclusions: Photosynthetic performance was in the series: Q. saponaria $>$ C. alba $\geq$ L. caustica, which can be attributed first to mesophyll conductance limitations, probably mediated by leaf anatomical traits and then to species specific foliage $\mathrm{N}$ partitioning strategies.

Keywords: Chloroplastic $\mathrm{CO}_{2}$ concentration; Electron transport; Mesophyll conductance; Rubisco carboxylation; Sclerophyllous species

\section{Background}

The biochemical model of leaf photosynthesis originally proposed by Farquhar et al. (1980) and later improved (von Caemmerer and Farquhar, 1981; Sharkey, 1985; Harley and Sharkey, 1991) is widely used in ecophysiological research for describing $\mathrm{CO}_{2}$ exchange processes and to scale carbon exchange from leaves to canopies (Baldocchi and Harley 1995; McMurtrie et al. 1992; Whitehead et al. 2004). In this model, photosynthesis is considered to be limited by the maximal rate of ribulose-1,5-bisphosphate (RuBP) carboxylase-oxygenase (Rubisco) carboxylation, $V_{\text {cmax }}$, and by the maximal electron transport rate driving

\footnotetext{
* Correspondence: hbown@uchile.cl

${ }^{1}$ Facultad de Ciencias Forestales y de la Conservación de la Naturaleza, Universidad de Chile, Casilla 9206, Santiago, Chile

Full list of author information is available at the end of the article
}

regeneration of RuBP, $J_{\max }$, and by triose phosphate utilization (TPU) (Farquhar et al. 1980; von Caemmerer 2000; von Caemmerer and Farquhar 1981). These parameters are fitted to the response of photosynthesis, $A$, to the $\mathrm{CO}_{2}$ concentration in the intercellular air spaces, $C_{\mathrm{i}}$, known as $A / C_{\mathrm{i}}$ curves. Values of $C_{\mathrm{i}}$, are estimated from stomatal conductance to $\mathrm{CO}_{2}$ transfer, $g_{\mathrm{s}}$, and the ambient $\mathrm{CO}_{2}$ concentration external to the leaf, $\mathrm{C}_{\mathrm{a}}$. This model has been used to explain the mechanisms of photosynthetic acclimation to elevated atmospheric $\mathrm{CO}_{2}$ (Griffin et al. 2000; Hogan et al. 1996; Kellomaki and Wang 1996; Murray et al. 2000; Turnbull et al. 1998), the influence of global warming on plant carbon budgets (Turnbull et al. 2002), and for identifying factors limiting photosynthesis under water stressed conditions in Mediterranean plants 
(Grassi and Magnani 2005; Gulias et al. 2002; Niinemets et al. 2009b), among others.

In most studies, the mesophyll conductance of $\mathrm{CO}_{2}$ from the intercellular air spaces to the sites of Rubisco carboxylation in the chloroplasts, $g_{\mathrm{m}}$, has been considered to be sufficiently large to be negligible (Farquhar et al. 1980). However, there is a growing awareness that the significance of $g_{\mathrm{m}}$ in limiting photosynthesis can be similar to the limitation imposed by stomata (Flexas et al. 2008; Harley et al. 1992; Loreto et al. 1992; von Caemmerer 2000; Warren and Adams 2006; Warren et al. 2003). As a result, $C_{\mathrm{i}}$ is greater than the $\mathrm{CO}_{2}$ concentration in the chloroplasts, $C_{\mathrm{c}}$, and values of $V_{\mathrm{cmax}}$ and $J_{\max }$ are underestimated when fitted to estimates of $C_{\mathrm{i}}$ rather than $C_{\mathrm{c}}$.

Arid and semiarid lands account for $41 \%$ of Chile's continental territory, covering about 31 million ha (Benites et al. 1994). Within this area, semiarid sclerophyllous (i.e. a woody plant with small coriaceous evergreen leaves dominant of the Mediterranean region) shrublands and forests extends from $32-36^{\circ} \mathrm{S}$ latitude $(\sim 345,000 \mathrm{ha})$ in Central Chile (Armesto et al. 2007; CONAF 1999); exhibiting high levels of endemism, and are therefore considered a priority for biodiversity conservation (Arroyo et al. 2004). These ecosystems are subjected to high radiative and water stresses that limit their development and reproduction (Cabrera 2002); and, additionally, have a long history of degradation by human activity, which may represent an important adaptive pressure (Galmes et al. 2007). Therefore, understanding how environmental limitations are imposed on the carbon budget is relevant to accurately estimate carbon uptake and water use by sclerophyllous species.

There is extensive work on comparisons of $g_{\mathrm{m}}$ between species and plant functional groups (Loreto et al. 1992; De Lucia et al. 2003; Hassiotou et al. 2009; Niinemets et al. 2009b). However, little is known about the extent to which $g_{\mathrm{m}}$ regulates the rate of photosynthesis in sclerophyllous species of central Chile. Consequently we chose to work with three native sclerophyllous species: Quillaja saponaria Mol., Cryptocarya alba Mol. Looser and Lithraea caustica Molina Hook et Arn., to determine stomatal, mesophyll and biochemical limitations to photosynthesis. Specifically, we assessed whether mesophyll conductance to $\mathrm{CO}_{2}$ induces similar constrains to photosynthesis across different sclerophyllous species.

\section{Methods}

Plant material

Plant material consisted of 15 randomly selected plants from each of the following species: Q. saponaria, C. alba and L. caustica, from a nursery of the Faculty of Forestry and Nature Conservation at University of Chile, Santiago, Chile. Seeds were sown in the winter 2008, and transferred during spring 2008 and spring 2009 to $12 \times 15 \mathrm{~cm}(0.25 \mathrm{~L})$ and $20 \times 30 \mathrm{~cm}(2 \mathrm{~L})$ black polyethylene bags filled with an even mixture of composted plant residues, soil and sand. No fertilizers were applied. Plants developed under $46 \%$ shading (in order to mimic the light environment experienced by saplings in their natural habitat) and received weekly irrigation during winter, and daily irrigation to field capacity in other seasons. At the time of measurements, we selected fifteen homogenous plants of Q. saponaria, C. alba and L. caustica which exhibited an average $( \pm 1$ SD) plant height of $82.9 \pm 14.4 \mathrm{~cm}, 63.4 \pm 18.9 \mathrm{~cm}$, and $47.6 \pm 15.3 \mathrm{~cm}$; and a collar diameter of $7.5 \pm 0.8 \mathrm{~mm}$, $9.1 \pm 1.4 \mathrm{~mm}$, and $11.0 \pm 2.6 \mathrm{~mm}$, respectively. All gas exchange and chlorophyll fluorescence measurements were taken in a laboratory without thermal regulation, with open windows to allow circulation of fresh air. Measurements took 45 days; with only one plant measured per day, spread in the summer period from December 20, 2010 to March 15, 2011; six months after plants were transferred from small to large containers. Gas exchange measurements for each individual plant typically took all day between 10 am and $6 \mathrm{pm}$; and followed the exact same sequence of measurements for all plants (see below). We alternated species each day in order to avoid differences brought about by day to day meteorological changes.

\section{Gas exchange measurements}

Simultaneous measurements of gas exchange and chlorophyll $a$ fluorescence were carried out on the 45 selected plants, using a portable photosynthesis system (CIRAS-2, PP Systems, MA, USA) equipped with an integrated chlorophyll fluorescence and gas exchange chamber (PLC6-U Auto Leaf Cuvette, PP System, MA, US). Plants were shifted from the nursery to the laboratory the day before measurements were undertaken.

For each plant, a fully-developed leaf in the upper third of the plant was chosen and placed inside a circular $2.5 \mathrm{~cm}^{2}$ (18 $\mathrm{mm}$ in diameter) cuvette. Temperature in the cuvette (block) was maintained at $25^{\circ} \mathrm{C}$ while leaf-to-air vapour pressure deficit $(V P D)$ was maintained below $1 \mathrm{kPa}$. Each leaf was left to equilibrate inside the cuvette for $10 \mathrm{~min}$ at about $368 \pm 3 \mu \mathrm{mol} \mathrm{mol}{ }^{-1} \mathrm{CO}_{2}$ concentration and saturating irradiance $\left(2,000 \mu \mathrm{mol}\right.$ photons $\mathrm{m}^{-2}$ $\left.\mathrm{s}^{-1}\right)$, before measuring the response of net assimilation $(A)$ to intercellular $\mathrm{CO}_{2}$ concentration $\left(C_{\mathrm{i}}\right)$. External $\mathrm{CO}_{2}$ concentration $\left(C_{\mathrm{a}}\right)$ was supplied with a $\mathrm{CO}_{2}$ mixer across the sequence $25,50,75,100,200,300,400,500,600,700,800$, $900,1000,1200$ and $1500 \mu \mathrm{mol} \mathrm{mol}^{-1}$, with saturating irradiance, $Q(400-700 \mathrm{~nm})$, maintained at 2,000 $\mu \mathrm{mol} \mathrm{m} \mathrm{m}^{-2} \mathrm{~s}^{-1}$. Measurements were recorded after values of $A, C_{\mathrm{i}}$ and $g_{\mathrm{s}}$ became stable but with a minimum waiting time of $3 \mathrm{~min}$ at each step within the sequence. At each value of $C_{\mathrm{i}}$, measurements of fluorescence for the light-adapted leaf were made simultaneously to the gas exchange measurements. Values of $F$ and $F_{\mathrm{m}}$ ' (the steady and maximal fluorescence 
respectively), were used to calculate photochemical efficiency of photosystem II, $\Phi_{\text {PSII }}$. The response of net assimilation to irradiance $(A / Q$ curves) was measured immediately after each $A / C_{\mathrm{i}}$ curve ended, across the $Q$ sequence: $0,50,100,150,200,300,400,500,800,1000$, $1200,1400,1600,1800$ and $2000 \mu \mathrm{mol} \mathrm{m}^{-2} \mathrm{~s}^{-1}$, with ambient $\mathrm{CO}_{2}$ concentration maintained at $368 \pm 3 \mu \mathrm{mol} \mathrm{mol}^{-1}$ using a $\mathrm{CO}_{2}$ mixer. The $A / C_{\mathrm{i}}$ and $A / Q$ curves were measured on the same foliage sample.

\section{Models fitted}

The biochemical model of leaf photosynthesis by Farquhar et al. (1980) describes the rate of photosynthesis $(A)$ as:

$$
A=\min \left\{A_{\mathrm{c}}, A_{\mathrm{q}}\right\}-R_{\mathrm{d}}
$$

where $A_{\mathrm{c}}$ and $A_{\mathrm{q}}$ are the photosynthetic rates limited by Rubisco carboxylation and by electron transport rate respectively, and $\min \{\}$ indicates the minimum of these two rates. $R_{\mathrm{d}}$ is the rate of daytime respiration resulting from processes other than photorespiration. The photosynthetic rate limited by Rubisco carboxylation $\left(A_{\mathrm{c}}\right)$ is given by:

$$
A_{\mathrm{c}}=V_{\mathrm{c} \max } \frac{C_{\mathrm{i}}-\Gamma^{*}}{C_{\mathrm{i}}+K_{\mathrm{c}}\left(1+O_{\mathrm{i}} / K_{\mathrm{o}}\right)}
$$

where $V_{\text {cmax }}$ is the maximum rate of Rubisco carboxylation under saturating $\mathrm{RuBP}$ and $\mathrm{CO}_{2}, \mathrm{C}_{\mathrm{i}}$ and $\mathrm{O}_{\mathrm{i}}$ are the intercellular $\mathrm{CO}_{2}$ and $\mathrm{O}_{2}$ concentrations, $\Gamma^{*}$ is the $\mathrm{CO}_{2}$ compensation concentration in the absence of day respiration, and $K_{\mathrm{c}}$ and $K_{\mathrm{o}}$ are the Michaelis constants for $\mathrm{CO}_{2}$ and $\mathrm{O}_{2}$, respectively.

The photosynthetic rate limited by $\mathrm{RuBP}$ regeneration driven by electron transport $\left(A_{\mathrm{q}}\right)$ is given by:

$$
A_{\mathrm{q}}=\frac{J\left(C_{\mathrm{i}}-\Gamma^{*}\right)}{4\left(C_{\mathrm{i}}+2 \Gamma^{*}\right)}
$$

where $J$ is the rate of electron transport at a given irradiance $Q$.

Prioul and Chartier (1977) described the response of $A$ to $Q$ by a non-rectangular hyperbola as:

$$
A=\frac{\alpha Q+A_{\mathrm{sat}}-\sqrt{\left(\alpha Q+\mathrm{A}_{\mathrm{sat}}\right)^{2}-4 \alpha \theta Q A_{\mathrm{sat}}}}{2 \theta}-\mathrm{R}_{\mathrm{dark}}
$$

where $\theta$ is the convexity of the non-rectangular hyperbola, $\alpha$ is the initial slope of the $A / Q$ curve (often referred as 'apparent maximum quantum efficiency'), $A_{\text {sat }}$ is the light-saturated photosynthetic capacity and $R_{\text {dark }}$ the respiration rate at zero irradiance. Individual $A / Q$ response curves were fitted using Eq. 4 in order to estimate $\alpha, A_{\text {sat }}$ and $R_{\text {dark }}$. The light saturation point, $Q_{\text {sat }}$, was calculated as the irradiance for which $90 \%$ of $A_{\text {sat }}$ was achieved.
Values of the rate of mitochondrial respiration in the light, $R_{\mathrm{d}}^{*}$, and the chloroplastic $\mathrm{CO}_{2}$ compensation point, $\Gamma^{*}$, were estimated for each sample using the Laisk method (von Caemmerer 2000). Briefly, the $A / C_{\mathrm{i}}$ response was measured at three levels of low irradiance $\left(Q=50,200\right.$ and $\left.400 \mu \mathrm{mol} \mathrm{m} \mathrm{m}^{-2} \mathrm{~s}^{-1}\right)$ for six increasing values of $C_{\mathrm{a}}$ from 25 to $400 \mu \mathrm{mol} \mathrm{CO} \mathrm{Col}^{-1}$. Linear relationships between $A$ and $C_{\mathrm{i}}$ were fitted and the point of intersection of the three lines was taken as $R_{\mathrm{d}}^{*}(y$-axis) and $\Gamma^{*}$ ( $x$-axis) (Figure 1$)$.

The photosynthesis model described by Farquhar et al. (1980) (Eq. 1) was fitted to the $A / C_{\mathrm{i}}$ and $A / C_{\mathrm{c}}$ curves by non-linear least squares regression (SigmaPlot, Version 12.1, SPSS, Chicago, IL). Values of $V_{\text {cmax }}$ and $R_{\mathrm{d}}$ were estimated from the lower part of the $A / C_{\mathrm{i}}$ or $A / C_{\mathrm{c}}$ curve $\left(C_{\mathrm{i}}\right.$ or $C_{\mathrm{c}}<220 \mu \mathrm{mol} \mathrm{mol}{ }^{-1}$ ) (Eq. 1 and 2 ), and these values were then used to estimate $J_{\max }$ over the entire range of measured $C_{\mathrm{i}}$ or $C_{\mathrm{c}}$ (Eq. 1,2 and 3). Michaelis-Menten constants of Rubisco for $\mathrm{CO}_{2}$ and $\mathrm{O}_{2}, K_{\mathrm{c}}$ and $K_{\mathrm{o}}$, used in the fitting $\left(25{ }^{\circ} \mathrm{C}\right)$ were $404.9 \mu \mathrm{mol} \mathrm{m^{-1 }}$ and $278.4 \mathrm{mmol} \mathrm{mol}^{-1}$, respectively as described by Bernacchi et al. (2001).

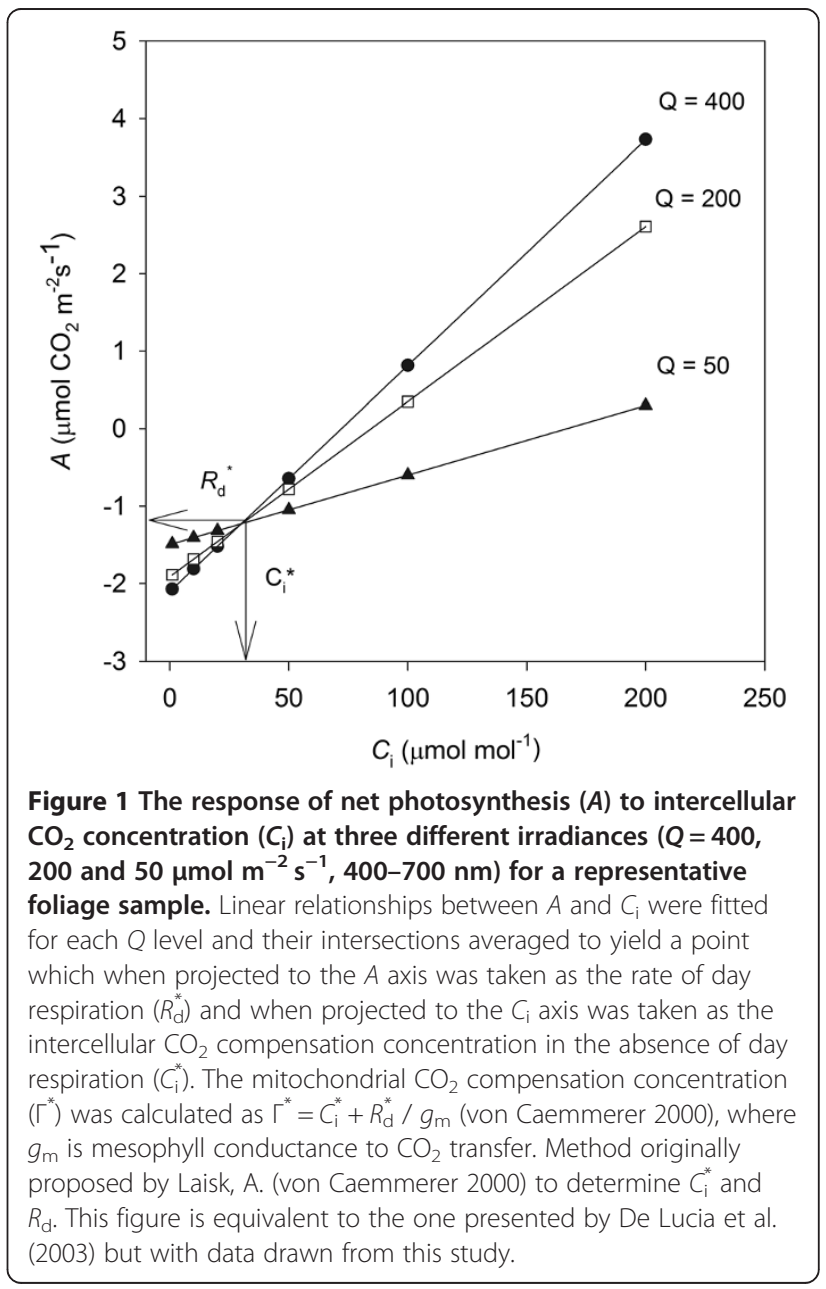




\section{Calculations of mesophyll conductance}

Mesophyll conductance, $g_{\mathrm{m}}$, was estimated using the "constant " method (Harley et al. 1992; Loreto et al. 1992) where $J$ is the rate of electron transport (Figure 2b). This method uses data in the RuBP-regeneration limited portion of the $A / C_{\mathrm{i}}$ curve, where rates of electron transport are constant. Within this region, further increases in photosynthesis with increasing $C_{\mathrm{i}}$ are due to suppression of photorespiration as the rate of carboxylation progressively substitutes the rate of oxygenation. Thus, photosynthesis is related to $C_{\mathrm{c}}$ and the relative $\mathrm{CO}_{2} / \mathrm{O}_{2}$ specificity of Rubisco, normally described by the chloroplastic $\mathrm{CO}_{2}$ compensation point, $\Gamma^{*}$. The constant $J$ method is sensitive to errors in both the rate of mitochondrial respiration in the light, $R_{\mathrm{d}}^{*}$, and $\Gamma^{*}$ and the approach assumes that both $J$ and $g_{\mathrm{m}}$ are constant across the range of $C_{\mathrm{a}}$ concentrations used for the measurements (Harley et al. 1992; Pons et al. 2009). The relationship of $g_{\mathrm{m}}$ with $\Gamma^{*}, R_{\mathrm{d}}^{*}$ and intercellular $\mathrm{CO}_{2}$ compensation point in the absence of day respiration, $C_{\mathrm{i}}^{*}$ is given by $\Gamma^{\prime \prime}=C_{\mathrm{i}}^{*}+R_{\mathrm{d}}^{* \prime} / g_{\mathrm{m}}$ (Peisker and Apel 2001; von Caemmerer 2000).

The photochemical efficiency of photosystem II ( $\left.\Phi_{\text {PSII }}\right)$ was estimated from chlorophyll fluorescence measurements as $\left(F_{\mathrm{m}}{ }^{\prime}-F\right) / F_{\mathrm{m}}{ }^{\prime}$, where $F$ and $F_{\mathrm{m}}$ ' are the steady and maximal fluorescence in the light-adapted sample respectively (Schreiber et al. 1994). The values of $\Phi_{\text {PSII }}$ are directly proportional to the rate of electron transport through photosystem II, and therefore can be used to determine the portion of the $A / C_{\mathrm{i}}$ curve where the rate of electron transport is constant (Genty et al. 1989) (Figure 2a). Optimal values for $g_{\mathrm{m}}$ were resolved iteratively from three or more measurements of photosynthesis at high values of $C_{\mathrm{i}}$ that correspond with constant rates of electron transport (Singsaas et al. 2004; Warren 2006). This was done using the Generalized Reduced Gradient Nonlinear Solving Method for nonlinear optimization included in the Solver Tools of Microsoft Excel with measurements of $A, C_{\mathrm{i}}, \Gamma^{*}, R_{\mathrm{d}}^{*}$ to resolve the value of $g_{\mathrm{m}}$ that best explained changes in photosynthesis with changes in $C_{\mathrm{i}}$ indicated by minimum variance in $J$ (Harley et al. 1992; Singsaas et al. 2004; Warren 2006) (Figure 2b).

\section{Stomatal and mesophyll limitations to photosynthesis}

$A / C_{\mathrm{i}}$ response and values for $g_{\mathrm{s}}$ and $g_{\mathrm{m}}$, were used to partition stomatal, mesophyll and biochemical limitations to photosynthesis. Values of stomatal conductance to $\mathrm{CO}_{2}$ transfer were calculated by $g_{\mathrm{s}}=A /\left(C_{\mathrm{a}}-C_{\mathrm{i}}\right)$ dividing values by 1.64 (Jones 1992). Relative stomatal limitations were calculated using the method of Farquhar and Sharkey (1982) as $L_{\mathrm{s}}=1-A_{\mathrm{a}-\mathrm{gs}} / A_{\mathrm{i}-\mathrm{gs}}$ where $A_{\mathrm{a}-\mathrm{gs}}$ and $A_{\mathrm{i} \text {-gs }}$ are the actual value of $A$ and the value estimated when $g_{\mathrm{s}}$ is infinite, respectively. Similarly, following Bernacchi et al. (2002), relative limitation to photosynthesis imposed by $g_{\mathrm{m}}$ was calculated as: $L_{\mathrm{m}}=1-A_{\mathrm{a}-\mathrm{gm}} / A_{\mathrm{i} \text {-gm }}$ where $A_{\mathrm{a} \text {-gm }}$ and
$A_{\mathrm{i}-\mathrm{gm}}$ are the actual value of $A$ and the value estimated when $g_{\mathrm{m}}$ is infinite, respectively. The $\mathrm{CO}_{2}$ concentration in the chloroplasts, $C_{\mathrm{c}}$, was calculated from $C_{\mathrm{c}}=C_{\mathrm{i}}-A / g_{\mathrm{m}}$.

\section{Foliage surface area and nutrient concentrations}

Following the completion of $A / C_{\mathrm{i}}$ and $A / Q$ curves, the leaf was carefully removed from the cuvette, scanned to determine leaf area by optical methods, dried at $70^{\circ} \mathrm{C}$ to constant mass and then both measurements used to calculate the foliage area to mass ratio, $M$. Foliage samples were finely ground, Dumas combusted and N concentrations determined by thermo conductivity (LECO, TruSpec CN, US) at the Laboratory of Soil and Foliar Analysis at Universidad Católica de Chile, Santiago, Chile. Nitrogen foliage concentrations are expressed on a hemisurface area basis $\left(N_{\mathrm{a}}\right)$ and photosynthetic nitrogen-use efficiency, $E_{\mathrm{N}}$, defined as $A_{\mathrm{sat}} / N_{\mathrm{a}}$.

\section{Data analysis}

All statistical analyses were undertaken at the plant level using The R System (R Core Team 2013). Variables were tested for normality and homogeneity of variance and transformations were made as necessary to meet the underlying statistical assumptions of the models used. All values are presented as means \pm 1 standard error $(n=15)$ unless stated otherwise. A one way analysis of variance was used to compare diffusional and biochemical limitations to photosynthesis between sclerophyllous species. Tukey's least significant difference test was used to distinguish among individual means where applicable with a confidence level of $P<0.05$. Differences in slopes and intercepts in the linear relationships between photosynthetic parameters and foliar nitrogen among sclerophyllous species were tested for significance by analysis of covariance.

\section{Results and discussion}

\section{Overall photosynthetic performance}

The Farquhar et al. (1980) model was fitted to the $A / C_{\mathrm{i}}$ curves while the Prioul and Chartier (1977) model to the $A / Q$ curves measured for each leaf sample $(n=45)$. There was excellent correspondence between modelled and observed data independent of the sclerophyllous species (Figure 3).

Light response curves (Figure 3a) were very similar among species up to an irradiance level of about $500 \mu \mathrm{mol}$ photons $\mathrm{m}^{-2} \mathrm{~s}^{-1}$, changing drastically thereafter with clearly distinct maximums of photosynthetic rates in the series: $Q$. saponaria $>C$. alba $>L$. caustica which reflects that the three species exhibited a similar initial pseudolinear slope of the $A / Q$ curve (the apparent maximum quantum efficiency: $\alpha$ ) averaging $0.033 \pm 0.007 \mathrm{~mol} \mathrm{CO}_{2}$ $\mathrm{mol}^{-1}$ quanta. The rate of photosynthesis at saturating irradiance $\left(2000 \mu \mathrm{mol} \mathrm{m}^{-2} \mathrm{~s}^{-1}\right)$ and ambient $\mathrm{CO}_{2}$ concentration $\left(A_{\text {sat }}\right)$, on the other hand, was significantly 

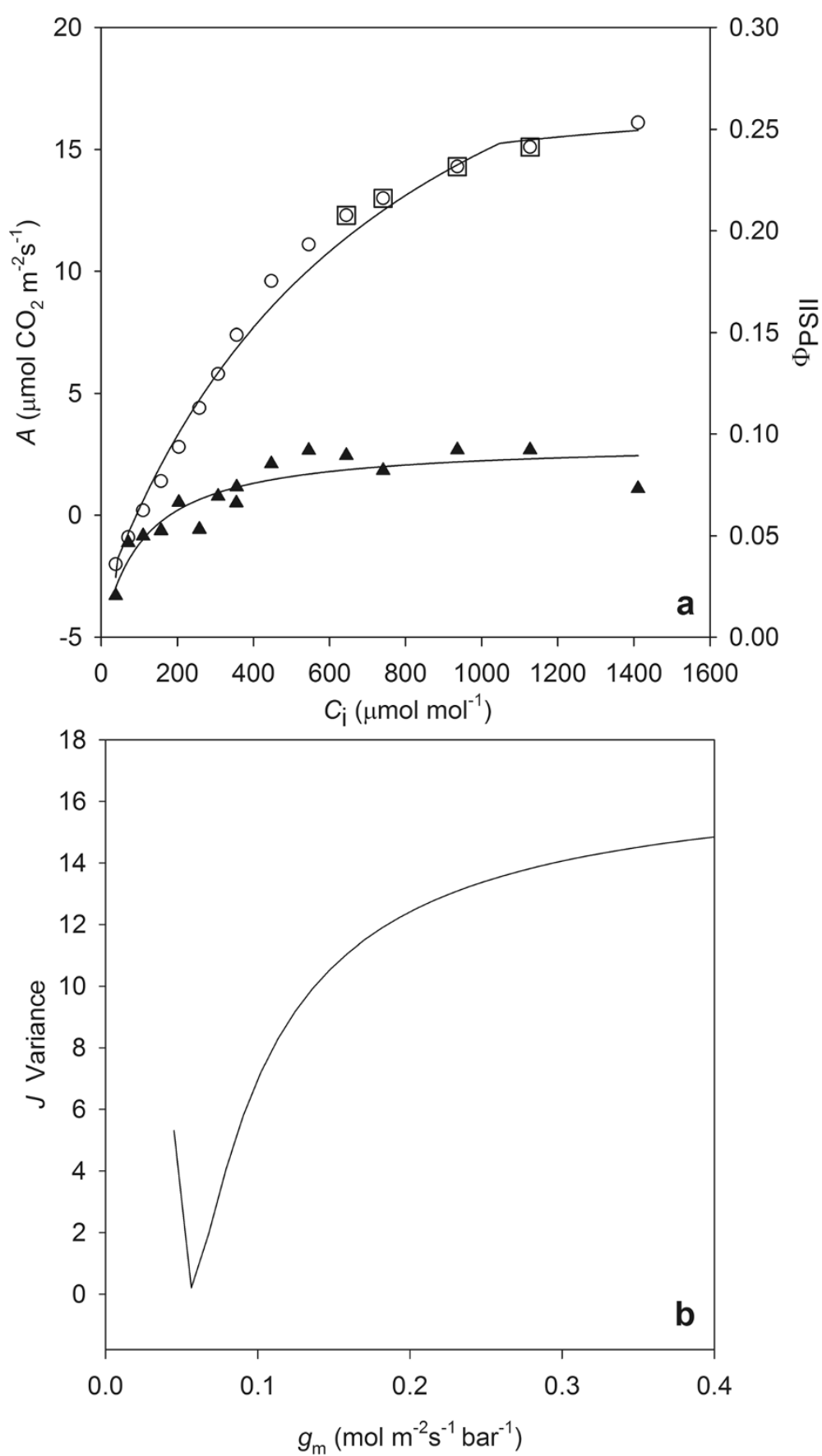

Figure 2 Graphic description of the constant $\boldsymbol{J}$ method to determine transfer conductance. (a) The rate of net photosynthesis ( $A$; open circles) and photochemical efficiency of photosystem II ( $\Phi_{\text {Pslli }}$ solid triangles) as a function of the intercellular $\mathrm{CO}_{2}$ concentration $\left(C_{\mathrm{i}}\right)$ for a representative foliage sample. Solid lines represent a least-squares fit to the $A / C_{i}$ and $\Phi_{\text {PSII }} / C_{i}$ response. Open squares are observed values used to estimate mesophyll conductance $\left(g_{m}\right)$. These values are within the portion of the $A / C_{i}$ response where $\Phi_{\text {psII }}$ indicated that electron transport rate was constant. (b) The variance of estimated electron transport rates, $J$, for different values of $g_{\mathrm{m}}$. Values of $J$ were estimated for each of the four $A$ values indicated as open squares in Figure $2 a$ using the equation given by Harley et al. (1992). The $g_{m}$ that minimized the variance of $J$ estimates for this foliage sample was $0.054 \mathrm{~mol} \mathrm{~m}^{-2} \mathrm{~s}^{-1} \mathrm{bar}^{-1}$. This figure is equivalent to the one presented by Harley et al. (1992) and De Lucia et al. (2003) but with data drawn from this study.

greater in Q. saponaria $\left(14.2 \pm 0.8 \mu \mathrm{mol} \mathrm{CO} \mathrm{CO}^{-2} \mathrm{~s}^{-1}\right)$ compared to C. alba $\left(9.5 \pm 0.4 \mu \mathrm{mol} \mathrm{CO} \mathrm{Cm}^{-2} \mathrm{~s}^{-1}\right)$ and L. caustica $\left(7.8 \pm 0.7 \mu \mathrm{mol} \mathrm{m}^{-2} \mathrm{~s}^{-1}\right)$ (Figure 3a; Table 1$)$.
The light saturation point, $Q_{\text {sat }}$, which followed a similar pattern as $A_{\text {sat, }}$, was consistently higher in Q. saponaria $\left(1168 \pm 57 \mu \mathrm{mol}\right.$ photons $\left.\mathrm{m}^{-2} \mathrm{~s}^{-1}\right)$ compared to C. alba 

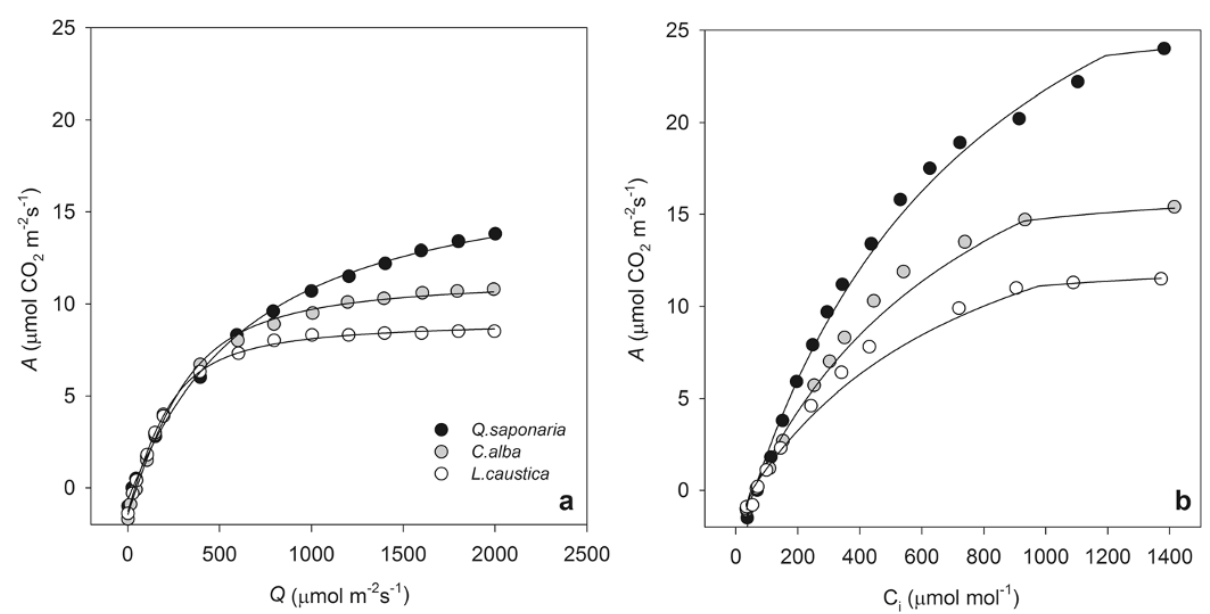

Figure 3 The response of net assimilation to either (a) photosynthetically active radiation $\left(A / Q\right.$ curve) or (b) internal $\mathrm{CO}_{2}$ concentration ( $A / C_{\mathrm{i}}$ curve) for $\mathbf{Q}$. saponaria, $\boldsymbol{C}$. alba and $\mathbf{L}$. caustica. The Prioul and Chartier (1977) model was fitted to the $A / Q$ curve while the Farquhar et al. (1980) model to the $A / C_{i}$ curve.

$\left(964 \pm 56 \mu \mathrm{mol}\right.$ photons $\left.\mathrm{m}^{-2} \mathrm{~s}^{-1}\right)$ and L. caustica $(987 \pm$ $65 \mu \mathrm{mol}$ photons $\left.\mathrm{m}^{-2} \mathrm{~s}^{-1}\right)$. The rate of respiration in the absence of light at ambient $\mathrm{CO}_{2}$ concentration $\left(R_{\text {dark }}\right)$ was $0.77 \pm 0.10 \mu \mathrm{mol} \mathrm{CO}_{2} \mathrm{~m}^{-2} \mathrm{~s}^{-1}$ independent of the species. The light compensation point, or the irradiance value at which the rate of photosynthesis equals zero, did not differ across species, being $38 \pm 4 \mu \mathrm{mol}$ photons $\mathrm{m}^{-2} \mathrm{~s}^{-1}$. The rate of transpiration at saturating irradiance $\left(2000 \mu \mathrm{mol} \mathrm{m} \mathrm{m}^{-2} \mathrm{~s}^{-1}\right)$ and ambient $\mathrm{CO}_{2}$ concentration (E) was $2831 \pm 309 \mu \mathrm{mol} \mathrm{H}_{2} \mathrm{O} \mathrm{m}^{-2} \mathrm{~s}^{-1}$ while the instantaneous water use efficiency $\left(\mathrm{E} / A_{\text {sat }}\right)$ was $337 \pm 41 \mathrm{~mol} \mathrm{H}_{2} \mathrm{O}$ $\mathrm{mol}^{-1} \mathrm{CO}_{2}$, unaffected by species (Table 1 ).

The response of photosynthetic rates $(A)$ to internal $\mathrm{CO}_{2}$ concentration $\left(C_{\mathrm{i}}\right)$ (Figure $3 \mathrm{~b}$ ), changed drastically among species for the whole range of $C_{\mathrm{i}}$ values in the series: Q. saponaria $>C$. alba $>L$. caustica. Consequently the initial slope of the $A / C_{\mathrm{i}}$ curves $\left(\mathrm{d} A / \mathrm{d} C_{\mathrm{i}}\right.$; often referred to as 'carboxylation efficiency') was greater in $Q$. saponaria (0.070) compared with $C$. alba (0.047) and L. caustica (0.038). A similar trend was observed for the rate of photosynthesis near saturating $C_{\mathrm{i}}\left(800 \mu \mathrm{mol} \mathrm{mol}{ }^{-1}\right), A_{\max }$, being 12.03, 17.01 and $23.81 \mu \mathrm{mol} \mathrm{CO}_{2} \mathrm{~m}^{-2} \mathrm{~s}^{-1}$ for L. caustica, C. alba and Q. saponaria, respectively (Table 1 ).

\section{Mesophyll conductance}

Mesophyll conductance $\left(g_{\mathrm{m}}\right)$ was similar between $L$. caustica $\left(0.060 \mathrm{~mol} \mathrm{CO}_{2} \mathrm{~m}^{-2} \mathrm{~s}^{-1} \mathrm{bar}^{-1}\right)$ and C. alba $(0.065 \mathrm{~mol}$ $\left.\mathrm{CO}_{2} \mathrm{~m}^{-2} \mathrm{~s}^{-1} \mathrm{bar}^{-1}\right)$, but collectively significantly lower than Q. saponaria $\left(0.097 \mathrm{~mol} \mathrm{CO}_{2} \mathrm{~m}^{-2} \mathrm{~s}^{-1} \mathrm{bar}^{-1}\right)$. Although unsignificantly, $g_{\mathrm{s}}$ tended to be greater for $Q$. saponaria (0.250 mol CO $\left.\mathrm{CO}^{-2} \mathrm{~s}^{-1}\right)$ compared to C. alba $(0.227 \mathrm{~mol}$ $\left.\mathrm{CO}_{2} \mathrm{~m}^{-2} \mathrm{~s}^{-1}\right)$ and L. caustica $\left(0.221 \mathrm{~mol} \mathrm{CO} \mathrm{m}^{-2} \mathrm{~s}^{-1}\right)$. The ratio $g_{\mathrm{m}} / g_{\mathrm{s}}$ was on average $0.47 \pm 0.08$, independent of species (Table 1). Relative limitations posed by mesophyll conductance to photosynthesis, $L_{\mathrm{m}},(0.40 \pm 0.02)$ were high compared to those imposed by stomata, $L_{\mathrm{s}}(0.07 \pm 0.01)$ and not significantly influenced by species. The average $\mathrm{CO}_{2}$ concentration in the intercellular air spaces $\left(C_{\mathrm{i}}\right)$ was $31.7 \mu \mathrm{mol} \mathrm{mol}{ }^{-1}$ lower than in the atmosphere $\left(C_{\mathrm{a}}\right)$, while the average $\mathrm{CO}_{2}$ concentration in the chloroplasts $\left(C_{\mathrm{c}}\right)$ was $130.6 \mu \mathrm{mol} \mathrm{mol}{ }^{-1}$ lower than in $C_{\mathrm{i}}$, independent of the species (Table 1).

The $g_{\mathrm{m}}$ values found in this study were generally lower than those reported for other plant functional groups. Flexas et al. (2008) argues that $g_{\mathrm{m}}$ is associated with leaf forms and plant functional groups, rather than evolutive trends: herbaceous plants exhibit generally the largest $g_{\mathrm{m}}$ values $\left(\sim 0.4 \mathrm{~mol} \mathrm{CO} \mathrm{m}^{-2} \mathrm{~s}^{-1} \mathrm{bar}^{-1}\right)$, perennial herbs and woody deciduous angiosperms display intermediate values $\left(\sim 0.2 \mathrm{~mol} \mathrm{CO} \mathrm{Cm}^{-2} \mathrm{~s}^{-1} \mathrm{bar}^{-1}\right)$, while woody evergreen plants exhibit $g_{\mathrm{m}}$ values slightly above and below $0.1 \mathrm{~mol}$ $\mathrm{CO}_{2} \mathrm{~m}^{-2} \mathrm{~s}^{-1}$ bar $^{-1}$ in angiosperms and gymnosperms, respectively. The mean value across all angiosperm sclerophyllous species studied was $0.073 \mathrm{~mol} \mathrm{CO}_{2} \mathrm{~m}^{-2} \mathrm{~s}^{-1} \mathrm{bar}^{-1}$, similar to those found by Niinemets et al. (2009b) for Australian sclerophyllous species $\left(0.087 \mathrm{~mol} \mathrm{CO}_{2} \mathrm{~m}^{-2} \mathrm{~s}^{-1} \mathrm{bar}^{-1}\right)$.

There seems to be a consistent pattern for sclerophyllous species to exhibit both low $g_{\mathrm{m}}$ and low $g_{\mathrm{m}} / g_{\mathrm{s}}$ values (Gulias et al. 2002; Niinemets et al. 2009b; Tomas et al. 2013; Warren 2004). Consequently, differences between $C_{\mathrm{a}}$ and $C_{\mathrm{i}}$ are relatively small compared to the difference between $C_{\mathrm{i}}$ and $C_{\mathrm{c}}$. This drawdown of $\mathrm{CO}_{2}$ implies that relative limitations imposed by mesophyll conductance to photosynthesis are much greater than those posed by stomata. Warren (2004) found that mesophyll limitations $\left(L_{\mathrm{m}} \sim 0.19\right.$ to 0.38$)$ were greater than stomatal limitations $\left(L_{\mathrm{s}} \sim 0.05\right.$ to 0.23$)$ for Eucalyptus globulus which are similar to our study. Equivalent mesophyll conductance limitations were observed for other sclerophyllous 
Table 1 Comparison of leaf and photosynthetic parameters for three common sclerophyll species in Central Chile

\begin{tabular}{|c|c|c|c|c|c|}
\hline \multirow[t]{2}{*}{ Variable } & \multirow[t]{2}{*}{ Units } & \multicolumn{3}{|c|}{ Schlerophyll species } & \multirow{2}{*}{$\begin{array}{l}\text { ANOVA } \\
\text { statistics }\end{array}$} \\
\hline & & L. caustica & C. alba & Q. saponaria & \\
\hline$A_{\text {sat }}$ & $\left(\mu \mathrm{mol} \mathrm{m} \mathrm{m}^{-2} \mathrm{~s}^{-1}\right)$ & $7.8 \pm 0.7 \mathrm{a}$ & $9.5 \pm 0.4 \mathrm{a}$ & $14.2 \pm 0.8 \mathrm{~b}$ & $* * *$ \\
\hline$a$ & $\left(\mathrm{~mol} \mathrm{~mol}{ }^{-1}\right)$ & $0.019 \pm 0.002$ & $0.024 \pm 0.002$ & $0.023 \pm 0.002$ & ns \\
\hline$R_{\text {dark }}$ & $\left(\mu \mathrm{mol} \mathrm{m} \mathrm{m}^{-2} \mathrm{~s}^{-1}\right)$ & $0.7 \pm 0.1$ & $1.0 \pm 0.2$ & $0.6 \pm 0.1$ & ns \\
\hline$Q_{\text {sat }}$ & $\left(\mu \mathrm{mol} \mathrm{m} \mathrm{m}^{-2} \mathrm{~s}^{-1}\right)$ & $987 \pm 65 a$ & $964 \pm 56 a$ & $1168 \pm 57 b$ & $*$ \\
\hline$Q_{\text {comp }}$ & $\left(\mu \mathrm{mol} \mathrm{m}^{-2} \mathrm{~s}^{-1}\right)$ & $36 \pm 8$ & $51 \pm 9$ & $27 \pm 4$ & ns \\
\hline E & $\left(\mu \mathrm{mol} \mathrm{H}_{2} \mathrm{O} \mathrm{m}^{-2} \mathrm{~s}^{-1}\right)$ & $2133 \pm 447$ & $2913 \pm 476$ & $3492 \pm 654$ & ns \\
\hline $1 /$ WUE & $\left(\mathrm{mol} \mathrm{H} \mathrm{H}_{2} \mathrm{Omol}^{-1} \mathrm{CO}_{2}\right)$ & $376 \pm 93$ & $347 \pm 57$ & $285 \pm 60$ & ns \\
\hline SLA & $\left(\mathrm{m}^{2} \mathrm{~kg}^{-1}\right)$ & $7 \pm 0.4 \mathrm{a}$ & $10 \pm 0.7 b$ & $8.7 \pm 0.5 \mathrm{ab}$ & $* * *$ \\
\hline$N_{a}$ & $\left(\mathrm{mmol} \mathrm{m}{ }^{-2}\right)$ & $120.2 \pm 8.9 a$ & $195.5 \pm 21 b$ & $165.8 \pm 17.6 \mathrm{ab}$ & $* *$ \\
\hline$E_{\mathrm{n}}$ & $\left(\mu \mathrm{mol} \mathrm{mol}{ }^{-1} \mathrm{~s}^{-1}\right)$ & $69.8 \pm 9.1 \mathrm{ab}$ & $56.4 \pm 6.2 \mathrm{a}$ & $95.9 \pm 8.8 b$ & ** \\
\hline$A_{\max }$ & $\left(\mu \mathrm{mol} \mathrm{mol}{ }^{-1} \mathrm{~s}^{-1}\right)$ & $12.03 \pm 0.86 a$ & $17.01 \pm 0.81 b$ & $23.81 \pm 1.18 c$ & $* * *$ \\
\hline$d A d d C i$ & $\left(\mathrm{~mol} \mathrm{~mol}{ }^{-1}\right)$ & $0.038 \pm 0.003 a$ & $0.047 \pm 0.002 \mathrm{a}$ & $0.070 \pm 0.004 b$ & $* * *$ \\
\hline$g_{\mathrm{m}}$ & $\left(\mathrm{mol} \mathrm{m}{ }^{-2} \mathrm{~s}^{-1} \mathrm{bar}^{-1}\right)$ & $0.06 \pm 0.005 a$ & $0.065 \pm 0.004 \mathrm{a}$ & $0.097 \pm 0.007 b$ & $* * *$ \\
\hline$g_{\mathrm{s}}$ & $\left(\mathrm{mol} \mathrm{m} \mathrm{m}^{-2} \mathrm{~s}^{-1}\right)$ & $0.221 \pm 0.03$ & $0.221 \pm 0.025$ & $0.25 \pm 0.018$ & ns \\
\hline$g_{\mathrm{m}} / g_{\mathrm{s}}$ & - & $0.54 \pm 0.18$ & $0.47 \pm 0.14$ & $0.43 \pm 0.06$ & ns \\
\hline$L_{s}$ & - & $0.07 \pm 0.01$ & $0.07 \pm 0.02$ & $0.08 \pm 0.01$ & ns \\
\hline$L_{m}$ & - & $0.35 \pm 0.03$ & $0.42 \pm 0.02$ & $0.43 \pm 0.02$ & ns \\
\hline$C_{a}$ & $\left(\mu \mathrm{mol} \mathrm{mol}{ }^{-1}\right)$ & $368.3 \pm 0.6$ & $368.7 \pm 1$ & $368.7 \pm 0.6$ & ns \\
\hline$C_{i}$ & $\left(\mu \mathrm{mol} \mathrm{mol}{ }^{-1}\right)$ & $337.7 \pm 7$ & $336.5 \pm 6.9$ & $333.6 \pm 3.7$ & ns \\
\hline$C_{c}$ & $\left(\mu \mathrm{mol} \mathrm{mol}{ }^{-1}\right)$ & $220 \pm 10.3$ & $202.2 \pm 8.2$ & $192.8 \pm 5.9$ & ns \\
\hline$V_{c \max }\left(C_{\mathrm{i}}\right)$ & $\left(\mu \mathrm{mol} \mathrm{m} \mathrm{m}^{-2} \mathrm{~s}^{-1}\right)$ & $26.8 \pm 2.1 \mathrm{a}$ & $32.6 \pm 1.1 \mathrm{a}$ & $49 \pm 2.6 b$ & $* * *$ \\
\hline$J_{\max }\left(C_{\mathrm{i}}\right)$ & $\left(\mu \mathrm{mol} \mathrm{m} \mathrm{m}^{-2} \mathrm{~s}^{-1}\right)$ & $56.3 \pm 4.1 \mathrm{a}$ & $79.6 \pm 3.8 \mathrm{a}$ & $111.4 \pm 5.6 b$ & $* * *$ \\
\hline$J_{\max } / V_{\text {cmax }}\left(C_{\mathrm{i}}\right)$ & - & $2.15 \pm 0.1$ & $2.44 \pm 0.07$ & $2.29 \pm 0.07$ & ns \\
\hline$V_{c \max }\left(C_{c}\right)$ & $\left(\mu \mathrm{mol} \mathrm{m} \mathrm{m}^{-2} \mathrm{~s}^{-1}\right)$ & $45.5 \pm 5.1 \mathrm{a}$ & $64.4 \pm 3.8 \mathrm{a}$ & $98.3 \pm 5.7 b$ & $* * *$ \\
\hline$J_{\max }\left(C_{c}\right)$ & $\left(\mu \mathrm{mol} \mathrm{m} \mathrm{m}^{-2} \mathrm{~s}^{-1}\right)$ & $60.4 \pm 4.4 a$ & $89.9 \pm 4.2 b$ & $126.4 \pm 6.1 c$ & $* * *$ \\
\hline$J_{\max } / V_{c \max }\left(C_{c}\right)$ & - & $1.41 \pm 0.07$ & $1.43 \pm 0.06$ & $1.31 \pm 0.05$ & ns \\
\hline$R_{d}^{*}$ & $\left(\mu \mathrm{mol} \mathrm{m} \mathrm{m}^{-2} \mathrm{~s}^{-1}\right)$ & $1.0 \pm 0.1 \mathrm{a}$ & $1.7 \pm 0.2 b$ & $1.5 \pm 0.1 b$ & $* * *$ \\
\hline$C_{i}^{*}$ & $\left(\mu \mathrm{mol} \mathrm{mol}{ }^{-1}\right)$ & $33 \pm 4.2 \mathrm{ab}$ & $23.2 \pm 2.3 a$ & $34 \pm 2.4 b$ & * \\
\hline$\Gamma^{*}$ & $\left(\mu \mathrm{mol} \mathrm{mol}{ }^{-1}\right)$ & $55.5 \pm 5.4$ & $56.8 \pm 4.1$ & $59.2 \pm 5.9$ & ns \\
\hline
\end{tabular}

Values are presented as means ( $\pm 1 \mathrm{SE}, n=15)$ for the light-saturated rate of photosynthesis $\left(A_{\text {sat }}\right.$ ), apparent maximum quantum efficiency (a), the rate of mitochondrial respiration at zero irradiance $\left(R_{\text {dark }}\right)$, light saturation $\left(Q_{\text {sat }}\right)$ and compensation point $\left(Q_{\text {comp }}\right)$, evapotranspiration $(E)$, the inverse of water use efficiency $(1 /$ WUE), specific leaf area $(\mathrm{SLA})$, the nitrogen content on area basis $\left(N_{\mathrm{a}}\right)$, photosynthetic nitrogen-use efficiency $\left(E_{\mathrm{N}}\right), C_{\mathrm{i}}$-saturated rate of photosynthesis $\left(A_{\text {max }}\right)$ and inicial slope of the $A / C_{\mathrm{i}}$ curve $\left(d A / d C_{\mathrm{i}}\right)$, mesophyll $\left(g_{\mathrm{m}}\right)$ and stomatal $\left(g_{\mathrm{s}}\right)$ conductance to $\mathrm{CO}_{2}$ diffusion, and their ratio $\left(g_{\mathrm{m}} / g_{\mathrm{s}}\right)$, relative stomatal, $L_{\mathrm{s}}$, and mesophyll, $L_{\mathrm{m}}$, limitations to photosynthesis, the external $\left(C_{\mathrm{a}}\right)$, intercellular $\left(C_{\mathrm{i}}\right)$ and chloroplastic $\left(C_{\mathrm{c}}\right) \mathrm{CO}_{2}$ concentration, maximal rate of Rubisco carboxylation $\left(V_{\mathrm{cmax}}\right)$, maximal rate of electron transport driving regeneration of $\operatorname{RuBP}\left(J_{\max }\right)$, the ratio $J_{\max } / V_{\mathrm{cmax}}$ on $C_{\mathrm{i}}$ and $C_{\mathrm{c}}$ basis, the rate of mitochondrial respiration in the light $\left(R_{\mathrm{d}}^{*}\right)$, the intercellular $\left(C_{\mathrm{i}}^{*}\right)$, and chloroplastic $\left(\Gamma^{*}\right) \mathrm{CO}_{2}$ compensation concentration in the absence of mitochondrial respiration. Separation of means was determined by a Tukey test where applicable. Different letters between species indicate that means were significantly different at $P<0.05$. Significance of species on photosynthetic parameters are shown as: ns, non significant; ${ }^{*}$, significant at $P<0.05 ;{ }^{* *}$, significant at $P<0.01$; ${ }^{* * *}$, significant at $P<0.001$.

species $\left(L_{\mathrm{m}} \sim 0.20-0.50\right)$ by Niinemets et al. (2009b). This seems to be explained by leaf anatomical traits such as thickness, density and the leaf mass to area ratio (Flexas et al. 2012; Niinemets et al. 2009b; Tomas et al. 2013) and also by tissue and cell anatomical traits, such as chloroplast surface area exposed to the intercellular air spaces, cell wall thickness and palisade tissue path length, among others (Tomas et al. 2013; Flexas et al. 2012; Tosens et al. 2012; Terashima et al. 2011; Hassiotou et al. 2009).
C.albaThere are only a few studies on leaf anatomical traits for the sclerophyllous species considered in this study. Q. saponaria generally exhibits lower density palisade parenchyma and spongy mesophyll compared to C. alba and L. caustica (Gotor 2008); and additionally L. caustica exhibits substantially thicker cell walls compared to the other sclerophyllous species (Montenegro 1984). We also found L.caustica leaves to be thicker and denser, as shown by its lower foliage area to mass ratio 
(M) $\left(7.0 \mathrm{~m}^{2} \mathrm{~kg}^{-1}\right)$, compared to Q. saponaria $\left(8.7 \mathrm{~m}^{2} \mathrm{~kg}^{-1}\right)$ and $C$. alba $\left(10 \mathrm{~m}^{2} \mathrm{~kg}^{-1}\right)$. Tomas et al. (2013) found that for sclerophyllous species $g_{\mathrm{m}}$ was strongly constrained by cell wall thickness (e.g. L. caustica). Such differences in leaf, tissue and cell anatomical traits may at least partially explain why values of $g_{\mathrm{m}}$ and photosynthetic rates are in the series: Q. saponaria $>C$. alba $\geq$ L. caustica.

In our study, values of $A_{\text {sat }}$ were strongly and positively correlated with $g_{\mathrm{m}}\left(A_{\mathrm{sat}}=1.92+100.49 g_{\mathrm{m}}, r^{2}=0.61\right.$, $\mathrm{P}<0.001)$. Intercepts $\left(F_{2,38}=8.07, P<0.01\right)$ but not slopes $\left(F_{2,38}=1.6, P=0.21\right)$ of this linear relationship were influenced by species (Figure 4 ). Values of $g_{\mathrm{s}}$ and $g_{\mathrm{m}}$ were uncorrelated $\left(r^{2}=0.03, P=0.29\right)$. An increase in the rate of photosynthesis with increasing $g_{\mathrm{m}}$ is consistent with previous findings from a wide range of species (Flexas et al. 2004; Grassi and Magnani 2005; Loreto et al. 1992; Niinemets et al. 2009b; Singsaas et al. 2004; Tomas et al. 2013; von Caemmerer and Evans 1991; Warren et al. 2003). Using the variable $J$ method and carbon isotopes to estimate $g_{\mathrm{m}}$ for 15 angiosperm species, Loreto et al. (1992) estimated that the slope of the relationship between $g_{\mathrm{m}}\left(\mathrm{mol} \mathrm{m} \mathrm{m}^{-2} \mathrm{~s}^{-1}\right.$ bar-1) and the rate of photosynthesis at saturating irradiance, $A_{\text {sat }}\left(\mu \mathrm{mol} \mathrm{m} \mathrm{m}^{-2} \mathrm{~s}^{-1}\right)$ was 0.025 (i.e. $A_{\text {sat }}=40 g_{\mathrm{m}}$ ). However, the magnitude of this slope in our study was 3.45 times greater. Grassi and Magnani (2005) estimated that the slope of the relationship

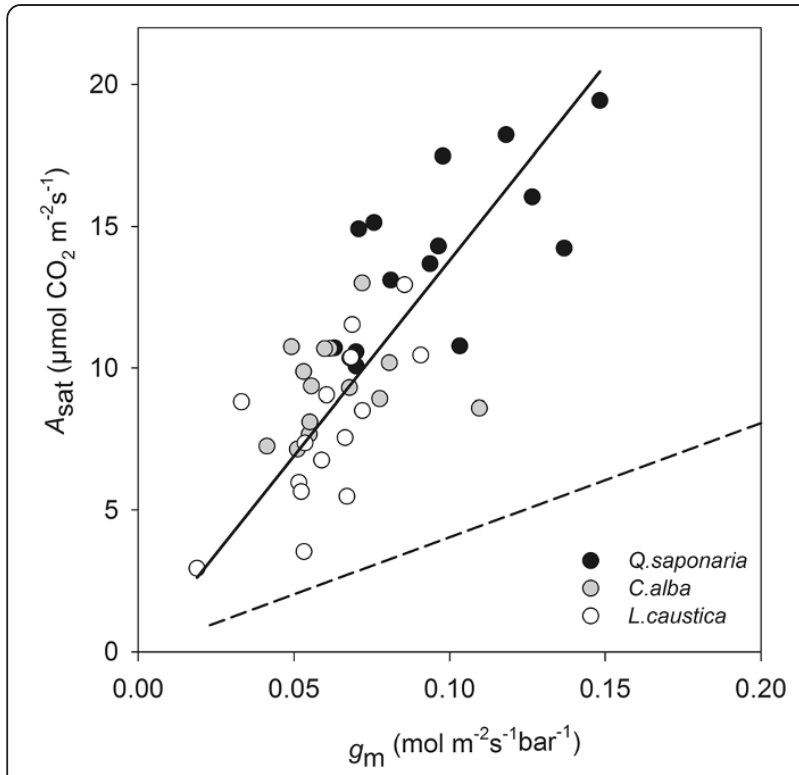

Figure 4 The relationship between Asat and $g_{\mathrm{m}}$. $A_{\text {sat }}$ stands for the rate of photosynthesis at saturating irradiance and ambient $\mathrm{CO}_{2}$ concentration; and, $g_{\mathrm{m}}$ for mesophyll conductance. The $A_{\text {sat }} / g_{\mathrm{m}}$ linear relationship was highly significant $\left(A_{\text {sat }}=2.4+109 g_{m}, r^{2}=0.6\right.$, $P<0.001$; without intercept: $\left.A_{\text {sat }}=138 g_{\mathrm{m}}\right)$. Intercepts $\left(F_{2,38}=8.07\right.$, $P<0.01)$ but not slopes $\left(F_{2,38}=1.6, P=0.21\right)$ of the $A_{\text {sat }} / g_{m}$ linear relationships differed between species. Dashed-lines are $A_{\text {sat }}=40 g_{\mathrm{m}}$, $r^{2}=0.89$, determined for 15 angiosperms species by Loreto et al. (1992). between $g_{\mathrm{m}}$ and $A_{\text {sat }}$ was 0.0132 (i.e. $A_{\text {sat }}=75.7 g_{\mathrm{m}}$ ) for oak trees, being our slope 1.8 times greater. This confirms that mesophyll conductance strongly limited the photosynthetic rates in the sclerophyllous species included in our study, compared to other plant groups; although they compare well with other sclerophyllous species.

The 'constant $J$ method' used to estimate $g_{\mathrm{m}}$ is sensitive to errors in both the rate of mitochondrial respiration in the light, $R_{\mathrm{d}}^{*}$, and the chloroplastic $\mathrm{CO}_{2}$ compensation concentration in the absence of mitochondrial respiration, $\Gamma^{*}$. Values of $\Gamma^{*}$ in our study were very similar across sclerophyllous species $\left(F_{2,41}=0.26, P=0.78\right)$, with a mean value of $50.7 \mu \mathrm{mol} \mathrm{mol}{ }^{-1}$ (Table 1$)$. In contrast, $R_{\mathrm{d}}^{*}$, was significantly lower $\left(F_{2,41}=9.87, P<0.001\right)$ in $L$. caustica $(1.0 \mu \mathrm{mol}$ $\left.\mathrm{CO}_{2} \mathrm{~m}^{-2} \mathrm{~s}^{-1}\right)$ compared to C. alba $\left(1.7 \mu \mathrm{mol} \mathrm{CO} \mathrm{CO}_{2} \mathrm{~m}^{-1}\right)$ and $Q$. saponaria $\left(1.5 \mu \mathrm{mol} \mathrm{CO} \mathrm{Cm}^{-2} \mathrm{~s}^{-1}\right)$ (Table 1$)$.

A recent paper by $\mathrm{Gu}$ and Sun (2014) suggests that the so-called Laisk method to estimate $\Gamma^{*}$ and $R_{\mathrm{d}}^{*}$ seems to be invalid, and hence an alternative estimate for $g_{\mathrm{m}}$ in our study would reduce the uncertainty related to our results. We tested whether our results for $g_{\mathrm{m}}$ withhold when using values found in the literature for $\Gamma^{*}$ and $R_{\mathrm{d}}^{*}$. We used values for tobacco from Brooks and Farquhar (1985) (Set 1: $R_{\mathrm{d}}=0.8 \mu \mathrm{mol} \mathrm{m}{ }^{-2} \mathrm{~s}^{-1}, \Gamma^{*}=36.9 \mu \mathrm{mol} \mathrm{mol}^{-1}$ ) and for spinach from Bernacchi et al. (2001) (Set 2:

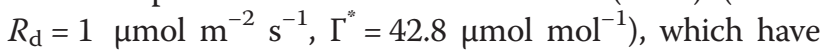
been commonly used to calculate $g_{\mathrm{m}}$ for evergreen species (Gallé et al. 2011; Hassiotou et al. 2009; Niinemets et al. 2009a; Niinemets et al. 2009b). We did not find significant differences within each species when comparing the three estimates of $g_{\mathrm{m}}$ i.e. using our estimates using the Laisk method, Set 1 and Set 2 (Q. saponaria: $P=0.48, C$. alba: $P=0.38$, L. caustica: $P=0.12)$. Tomas et al. $(2013 \mathrm{a}, \mathrm{b})$ performed a similar analysis for deciduous, semideciduous and evergreen trees and herbs plants, obtaining similar values of $g_{\mathrm{m}}$ independent of the values chosen for $\Gamma^{*}$ y $R_{\mathrm{d}}^{*}$. This shows that our results hold independent of having used the Laisk method to estimate $\Gamma^{*} \mathrm{y} R_{\mathrm{d}}^{*}$.

\section{Biochemical limitations to photosynthesis}

Values of $V_{\text {cmax }}$ (range 13-66, mean $36 \mu \mathrm{mol} \mathrm{m} \mathrm{m}^{-2} \mathrm{~s}^{-1}$ ) and $J_{\max }$ (range 33-148, mean $82 \mu \mathrm{mol} \mathrm{m} \mathrm{m}^{-2} \mathrm{~s}^{-1}$ ) in our study were within the range compiled for $109 \mathrm{C}_{3}$ plant species by Wullschleger (1993) ( $V_{\text {cmax }}$ : range 6-194, mean $64 \mu \mathrm{mol} \mathrm{m} \mathrm{m}^{-2} \mathrm{~s}^{-1} ; J_{\max }$ : range $17-372$, mean 134 $\mu \mathrm{mol} \mathrm{m} \mathrm{m}^{-2} \mathrm{~s}^{-1}$ ). Wullschleger (1993) also provided specific values of $V_{\text {cmax }}$ (range 11-119, mean $47 \mu \mathrm{mol} \mathrm{m}^{-2} \mathrm{~s}^{-1}$ ) and $J_{\max }$ (range 29-237, mean $104 \mu \mathrm{mol} \mathrm{m} \mathrm{m}^{-2} \mathrm{~s}^{-1}$ ) for temperate hardwoods and sclerophyllous species $\left(V_{\mathrm{cmax}}\right.$ : range 35-71, mean $53 \mu \mathrm{mol} \mathrm{m}{ }^{-2} \mathrm{~s}^{-1}$; $J_{\max }$ : range 94-167, mean $122 \mu \mathrm{mol} \mathrm{m} \mathrm{m}^{-2} \mathrm{~s}^{-1}$ ); which are similar to the ones found in our study. Pena-Rojas et al. (2004) observed values of $29 \mu \mathrm{mol} \mathrm{CO} \mathrm{CO}^{-2} \mathrm{~s}^{-1}$ and $59 \mu \mathrm{mol}$ electrons $\mathrm{m}^{-2} \mathrm{~s}^{-1}$ for $V_{\text {cmax }}$ and $J_{\max }$, respectively for Quercus ilex. Niinemets 
et al. (2009b) observed values of $37 \mu \mathrm{mol} \mathrm{CO} \mathrm{CO}_{2} \mathrm{~m}^{-2} \mathrm{~s}^{-1}$ and $89 \mu \mathrm{mol}$ electrons $\mathrm{m}^{-2} \mathrm{~s}^{-1}$ for $V_{\text {cmax }}$ and $J_{\max }$, respectively for different Australian sclerophyllous species. This emphasizes the fact that photosynthetic capacity in our study was more limited by $g_{\mathrm{m}}$ than by biochemical limitations, as our values of $V_{\mathrm{cmax}}$ and $J_{\max }$ were greater than those reported by Pena-Rojas et al. (2004) and Niinemets et al. (2009b) and comparable to averages for $\mathrm{C}_{3}$ hardwoods.

The maximal rate of Rubisco carboxylation $\left(V_{\mathrm{cmax}}\right)$ calculated on a $C_{\mathrm{i}}$ basis, were significantly greater in $Q$. saponaria $\left(49.0 \mu \mathrm{mol} \mathrm{CO}_{2} \mathrm{~m}^{-2} \mathrm{~s}^{-1}\right.$ ) compared to $C$. alba $\left(32.6 \mu \mathrm{mol} \mathrm{CO} \mathrm{CO}^{-2} \mathrm{~s}^{-1}\right)$ and L. caustica $\left(26.8 \mu \mathrm{mol} \mathrm{CO}_{2}\right.$ $\mathrm{m}^{-2} \mathrm{~s}^{-1}$ ) (Table 1). Corresponding values of $V_{\mathrm{cmax}}$ on a $C_{\mathrm{c}}$ basis were 98.3, 64.4 and $45.5 \mu \mathrm{mol} \mathrm{CO} \mathrm{CO}^{-2} \mathrm{~s}^{-1}$, respectively. Therefore, values of $V_{\mathrm{cmax}}$ calculated on a $C_{\mathrm{c}}$ basis were $101 \%, 97 \%$ and $70 \%$ greater than those on a $C_{\mathrm{i}}$ basis for Q. saponaria, C. alba and L. caustica, respectively.

Similar to $V_{\text {cmax }}$, the maximal rate of electron transport driving regeneration of $\operatorname{RuBP}\left(J_{\max }\right)$ calculated on a $C_{\mathrm{i}}$ basis, were significantly greater in $Q$. saponaria (111.4 $\mu \mathrm{mol}$ electrons $\mathrm{m}^{-2} \mathrm{~s}^{-1}$ ) compared to $C$. alba $\left(79.6 \mu \mathrm{mol}\right.$ electrons $\left.\mathrm{m}^{-2} \mathrm{~s}^{-1}\right)$ and $L$. caustica $(56.3 \mu \mathrm{mol}$ electrons $\mathrm{m}^{-2} \mathrm{~s}^{-1}$ ) (Table 1). Corresponding values of $J_{\max }$ on a $C_{\mathrm{c}}$ basis were $126.4,89.9$ and $60.4 \mu \mathrm{mol}$ electrons $\mathrm{m}^{-2} \mathrm{~s}^{-1}$, respectively. Therefore, values of $J_{\max }$ were $13 \%, 13 \%$ and $7 \%$ greater on a $C_{\mathrm{c}}$ than a $C_{\mathrm{i}}$ basis for $Q$. saponaria, C. alba and $L$. caustica, respectively.

Although there were significant differences in values of $J_{\max }$ and $V_{\text {cmax }}$ among species, the $J_{\max } / V_{\text {cmax }}$ ratio was constant both on a $C_{\mathrm{i}}(2.29 \pm 0.05)$ and $C_{\mathrm{c}}(1.38 \pm 0.04)$ basis across species (Table 1). Similarly, the relationship between $J_{\max }$ and $V_{\text {cmax }}$ was highly significant both on a $C_{\mathrm{i}}$ $\left.U_{\max }=2.267 V_{\text {cmax }}, r^{2}=0.82, P<0.001\right)$ and $C_{\mathrm{c}}\left(J_{\max }=1.288\right.$ $V_{\text {cmax }}, r^{2}=0.81, P<0.001$ ) basis (Figure 5).

Most values of $V_{\text {cmax }}$ and $J_{\max }$ reported in the literature are calculated from $A / C_{\mathrm{i}}$ response curves, rather than $A / C_{\mathrm{c}}$ curves, with the implicit assumption that mesophyll conductance is infinitely large. When this assumption is invalid, values of $V_{\mathrm{cmax}}$ and $J_{\max }$ are underestimated (Ethier and Livingston 2004; Ethier et al. 2006; Grassi and Magnani 2005; Harley et al. 1992; Long and Bernacchi 2003; Loreto et al. 1992; Manter and Kerrigan 2004; von Caemmerer 2000; Niinemets et al. 2009a). To prove this assumption Grassi and Magnani (2005) showed that the relationship between $V_{\text {cmax,ci }}$ and $V_{\text {cmax,cc }}$ values result in a slope of $1.62\left(r^{2}=0.94\right)$, showing that the $C_{\mathrm{i}}$ calculation underestimated the real photosynthetic capacity of the leaf. This relation is similar to the one found in our study, which resulted in a slope of $1.28\left(r^{2}=0.76\right)$.

There is mounting evidence that $g_{\mathrm{m}}$ changes with chloroplastic $\mathrm{CO}_{2}$ concentration and irradiance, although some of that variation can be an artifact due to the mathematical methods employed (Gu and Sun 2014). Also

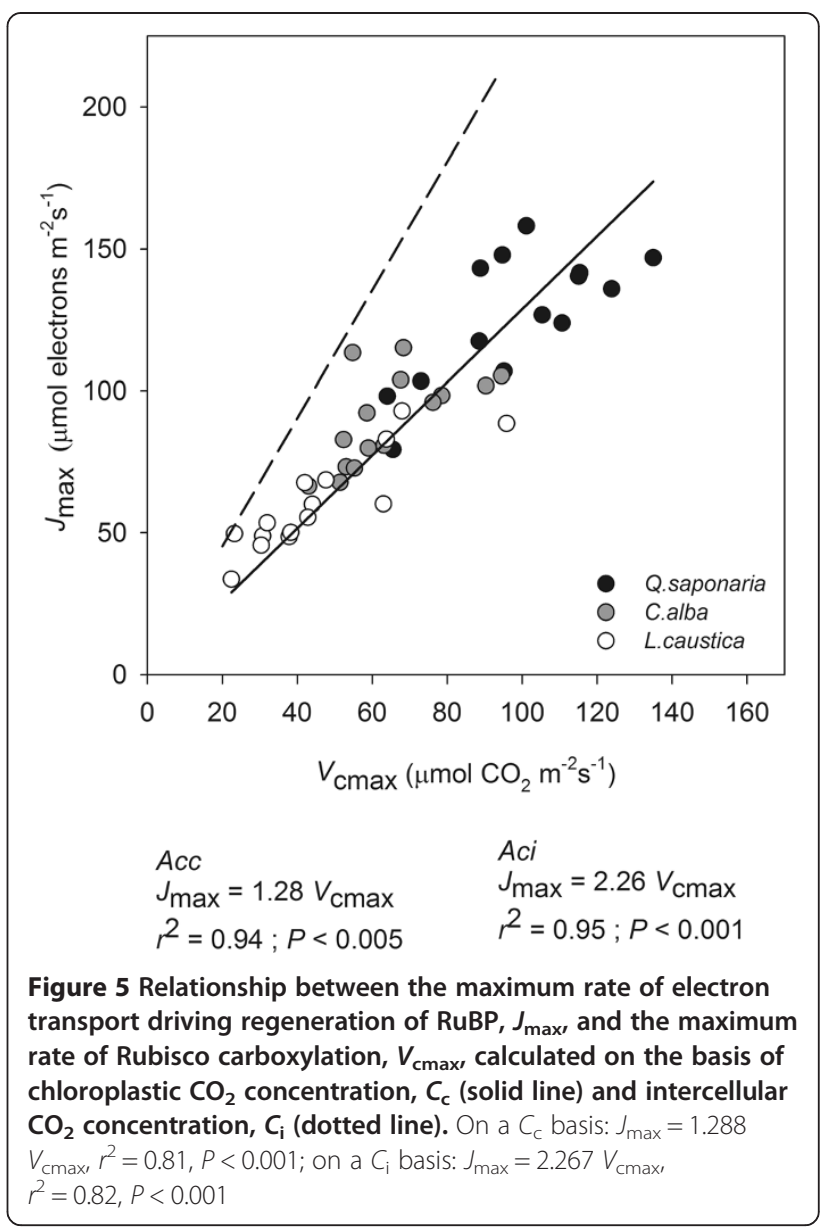

Tholen et al. (2012) suggests there are limitations in the precise estimate of $g_{\mathrm{m}}$ when taking several $A$ values from varying $\mathrm{CO}_{2}$ concentrations and rates of photorespiration to estimate $g_{\mathrm{m}}$. Taking aside artefactual responses, it seems that $g_{\mathrm{m}}$ initially increases, then peaks to decline thereafter with increasing $C_{\mathrm{c}}$; while $g_{\mathrm{m}}$ seems to increase with irradiance for the same level of $C_{\mathrm{c}}$ (Flexas et al. 2007). We are aware that converting $A / C_{\mathrm{i}}$ into $A / C_{\mathrm{c}}$ curves assuming a constant $g_{\mathrm{m}}$ can be invalid; but still useful for comparing our results with previous studies. For instance, the parameters and results found in our study were similar for the photosynthesis model stated by Farquhar et al. (1980) with model parameters in normal scenarios of $V_{\text {cmax }} \sim 50 \mu \mathrm{mol}$ $\mathrm{CO}_{2} \mathrm{~m}^{-2} \mathrm{~s}^{-1}, J_{\max } \sim 125 \mu \mathrm{mol}$ electrons $\mathrm{m}^{-2} \mathrm{~s}^{-1}$, and dark respiration rates $\sim 1.25 \mu \mathrm{mol} \mathrm{CO}_{2} \mathrm{~m}^{-2} \mathrm{~s}^{-1}$. These values were approximate to an 'average' $\mathrm{C}_{3}$ leaf based on $C_{\mathrm{c}^{-}}$ derived estimates and in the range of the results for the three sclerophyllous species of our study; therefore emphasizing that our species were more limited by $g_{\mathrm{m}}$ that biochemical parameters. We are also aware that using 'standard' Rubisco kinetics from tobacco to calculate $g_{\mathrm{m}}$, $V_{\text {cmax }}$ and $J_{\max }$ may lead to biases (Walker et al. 2013) to parameterize photosynthesis in the sclerophyllous 
species considered in this study. This emphasizes the need for future work to estimate Rubisco kinetics for sclerophyllous species in central Chile.

\section{Foliar nitrogen and photosynthetic parameters}

Photosynthetic rates are known to be closely related to foliar nitrogen concentrations (Field and Mooney 1986; Walcroft et al. 1997; Grassi et al. 2002; Ripullone et al. 2003). This is explained by the high proportion of total nitrogen partitioned to the carboxylating enzyme Rubisco (Sage and Pearcy 1987; Evans 1989; Warren and Adams 2002; Takashima et al. 2004) and also by the strong coupling effect among capacities $V_{\text {cmax }}$ and $J_{\max }$ (von Caemmerer and Farquhar 1981; Wullschleger 1993; Sharkey 1985).

At the plant level, observed $N_{\mathrm{a}}$ ranged almost sixfold from 54 to $339 \mathrm{mmol} \mathrm{N} \mathrm{m}^{-2}$ being significantly greater in C. alba $\left(195.5 \mathrm{mmol} \mathrm{m}^{-2}\right.$ ) compared to $Q$. saponaria $\left(165.8 \mathrm{mmol} \mathrm{m}^{-2}\right)$ and L. caustica $\left(120.2 \mathrm{mmol} \mathrm{m}^{-2}\right)$ (Table 1). Values of $g_{\mathrm{m}}$ were uncorrelated to $N_{\mathrm{a}}\left(r^{2}=0.001\right.$, $P=0.40)$; but as expected values of $V_{\mathrm{cmax}}$ and $J_{\max }$ on a $C_{\mathrm{i}}$ basis significantly increased with $N_{\mathrm{a}}\left(F_{1,38}>5.95, P<\right.$ 0.019). Intercepts $\left(F_{2,38}>31.3, P<0.001\right)$ but not slopes $\left(F_{2,38}<1.42, P>0.25\right)$ of the $V_{\text {cmax }} / N_{\mathrm{a}}$ and $J_{\max } / N_{\mathrm{a}}$ linear relationships were significantly different between species $\left(V_{\text {cmax }}=a+0.075 N_{\mathrm{a}}\right.$, with $a=17.728$ for $L$. caustica, $a=32.489$ for C. alba, $a=39.204$ for $Q$. saponaria, $r^{2}=0.61, P<0.001 ; J_{\max }=a+0.149 N_{\mathrm{a}}$, with $a=38.349$ for $L$. caustica, $a=85.976$ for $C$. alba, $a=101.296$ for Q. saponaria, $\left.r^{2}=0.62, P<0.001\right)$. It is worth noting that L.caustica exhibited the lowest intercept followed by C. alba and Q. saponaria consistently for both the $V_{\text {cmax }} / N_{\mathrm{a}}$ and the $J_{\max } / N_{\mathrm{a}}$ relationships which can be attributed to reasons other than foliage $\mathrm{N}$ (i.e. foliage $\mathrm{N}$ was accounted for in the slope of these relationships). We then may speculate that intercept differences among species can be attributed to distinct leaf $\mathrm{N}$ investment strategies. Consistently we found significant differences in Nitrogen use efficiency $\left(E_{\mathrm{n}}\right)$, being greatest in Q. saponaria $\left(95.9 \mu \mathrm{mol} \mathrm{CO}_{2}\right.$ mol $\left.\mathrm{N} \mathrm{s}^{-1}\right)$, compared to L. caustica $(69.8 \mu \mathrm{mol} \mathrm{CO} 2 \mathrm{~mol}$ $\mathrm{N} \mathrm{s}^{-1}$ ) and C. alba $\left(56.4 \mu \mathrm{mol} \mathrm{CO}_{2} \mathrm{~mol} \mathrm{~N} \mathrm{~s}^{-1}\right)$ (Table 1). Such differences in $E_{\mathrm{n}}$, may suggest that $Q$. saponaria, that exhibits a greater photosynthetic capacity, may invest proportionally more $\mathrm{N}$ to Rubisco compared to $L$. caustica and C. alba that exhibit poorer photosynthetic performance.

\section{Conclusions}

In conclusion, values of stomatal conductance, $g_{\mathrm{s}}$, were greater than those of mesophyll conductance, $g_{\mathrm{m}}$, while their ratio $\left(g_{\mathrm{m}} / g_{\mathrm{s}}\right)$ was not influenced by species, being on average 0.47 . Therefore, the relative limitations imposed by $g_{\mathrm{m}}$ were high $\left(L_{\mathrm{m}} \sim 0.40, C_{\mathrm{i}^{-}}\right.$ $C_{\mathrm{c}} \sim 131 \mu \mathrm{mol} \mathrm{mol}{ }^{-1}$ ) compared to those imposed by $g_{\mathrm{s}}\left(L_{\mathrm{s}} \sim 0.07, C_{\mathrm{a}}-C_{\mathrm{i}} \sim 32 \mu \mathrm{mol} \mathrm{mol}^{-1}\right)$. Consequently photosynthetic rates in our study were mainly limited by $g_{\mathrm{m}}$ as biochemical limitations $V_{\mathrm{cmax}}$ and $J_{\max }$ compare well to averages for $\mathrm{C}_{3}$ plants. Photosynthetic performance was in the series: $Q$. saponaria $>C$. alba $\geq L$. caustica which can be attributed first to mesophyll conductance limitations, probably mediated by leaf anatomical traits and then to species specific foliage $\mathrm{N}$ partitioning strategies.

\section{Appendix}

Abbreviations used throughout the text can be found in Table 2.

\section{Table 2 Abbreviations}

\begin{tabular}{|c|c|c|}
\hline Symbol & Description & Units \\
\hline$A_{\text {sat }}$ & $\begin{array}{l}\text { light-saturated rate of photosynthesis } \\
\text { at ambient } C_{a}\end{array}$ & $\mu \mathrm{mol} \mathrm{m} \mathrm{m}^{-2} \mathrm{~s}^{-1}$ \\
\hline$R_{\text {dark }}$ & respiration rate at zero irradiance & $\mu \mathrm{mol} \mathrm{m} \mathrm{m}^{-2} \mathrm{~s}^{-1}$ \\
\hline$Q_{\text {sat }}$ & $\begin{array}{l}\text { Light saturation point determined as } \\
\text { the Q value for which assimilation is } \\
90 \% \text { of Asat }\end{array}$ & $\mu \mathrm{mol} \mathrm{m} \mathrm{m}^{-2} \mathrm{~s}^{-1}$ \\
\hline$Q_{\text {comp }}$ & $\begin{array}{l}\text { Light compensation point determined } \\
\text { as the } \mathrm{Q} \text { value for which the rate of } \\
\text { photosynthesis exactly matches the } \\
\text { rate of respiration }\end{array}$ & $\mu \mathrm{mol} \mathrm{m} \mathrm{m}^{-2} \mathrm{~s}^{-1}$ \\
\hline a & apparent maximum quantum efficiency & $\mathrm{mol} \mathrm{mol}-1$ \\
\hline$C_{a}$ & $\begin{array}{l}\mathrm{CO}_{2} \text { concentration in the air outside } \\
\text { the leaf }\end{array}$ & $\mu \mathrm{mol} \mathrm{mol}{ }^{-1}$ \\
\hline$C_{i}$ & $\begin{array}{l}\mathrm{CO}_{2} \text { concentration in intercellular air } \\
\text { spaces }\end{array}$ & $\mu \mathrm{mol} \mathrm{mol}{ }^{-1}$ \\
\hline $\mathrm{C}_{\mathrm{c}}$ & $\mathrm{CO}_{2}$ concentration in the chloroplast & $\mu \mathrm{mol} \mathrm{mol}{ }^{-1}$ \\
\hline$\Gamma^{*}$ & chloroplastic $\mathrm{CO}_{2}$ compensation point & $\mu \mathrm{mol} \mathrm{mol}{ }^{-1}$ \\
\hline$C_{\mathrm{i}}^{*}$ & $\begin{array}{l}\text { intercellular } \mathrm{CO}_{2} \text { compensation point } \\
\text { in the absence of day respiration }\end{array}$ & $\mu \mathrm{mol} \mathrm{mol}{ }^{-1}$ \\
\hline$R_{\mathrm{d}}^{*}$ & $\begin{array}{l}\text { rate of mitochondrial respiration in } \\
\text { the light }\end{array}$ & $\mu \mathrm{mol} \mathrm{m} \mathrm{m}^{-2} \mathrm{~s}^{-1}$ \\
\hline$E_{N}$ & $\begin{array}{l}\text { instantaneous photosynthetic nitrogen } \\
\text { use efficiency }\end{array}$ & $\mu \mathrm{mol} \mathrm{mol} \mathrm{m}^{-1} \mathrm{~s}^{-1}$ \\
\hline$L_{s}$ & $\begin{array}{l}\text { relative stomatal (plus boundary layer) } \\
\text { limitation to photosynthesis }\end{array}$ & $\%$ \\
\hline$L_{m}$ & $\begin{array}{l}\text { relative mesophyll limitations to } \\
\text { photosynthesis }\end{array}$ & $\%$ \\
\hline$g_{\mathrm{s}}$ & $\begin{array}{l}\text { stomatal (plus boundary layer) } \\
\text { conductance to } \mathrm{CO}_{2} \text { diffusion }\end{array}$ & $\mathrm{mol} \mathrm{m} \mathrm{m}^{-2} \mathrm{~s}^{-1}$ \\
\hline$g_{\mathrm{m}}$ & $\begin{array}{l}\text { Mesophyll transfer conductance to } \\
\mathrm{CO}_{2} \text { diffusion }\end{array}$ & $\mathrm{mol} \mathrm{m}{ }^{-2} \mathrm{~s}^{-1}$ bar $^{-1}$ \\
\hline$V_{\text {cmax }}$ & $\begin{array}{l}\text { in vivo maximum rate of ribulose-1, } \\
\text { 5-bisphosphate (RuBP) carboxylase- } \\
\text { oxygenase (Rubisco) carboxylation }\end{array}$ & $\mu \mathrm{mol} \mathrm{CO}_{2} \mathrm{~m}^{-2} \mathrm{~s}^{-1}$ \\
\hline$J_{\max }$ & $\begin{array}{l}\text { electron transport driving regeneration } \\
\text { of RuBP }\end{array}$ & $\begin{array}{l}\mu \mathrm{mol} \text { electrons } \\
\mathrm{m}^{-2} \mathrm{~s}^{-1}\end{array}$ \\
\hline$A_{\max }$ & $\begin{array}{l}\text { the rate of photosynthesis near } \\
\text { saturating } C_{\mathrm{i}}\left(800 \mu \mathrm{mol} \mathrm{mol}{ }^{-1}\right)\end{array}$ & umol $\mathrm{CO}_{2} \mathrm{~m}^{-2} \mathrm{~s}^{-1}$ \\
\hline$N_{a}$ & $\begin{array}{l}\text { foliage nitrogen concentration on an } \\
\text { area basis }\end{array}$ & $\mathrm{mmol} \mathrm{m}{ }^{-2}$ \\
\hline M & Leaf area to mass ratio & $\mathrm{m}^{2} \mathrm{~kg}^{-1}$ \\
\hline VPD & Leaf-to-air vapour pressure deficit & $\mathrm{kPa}$ \\
\hline
\end{tabular}




\section{Competing interests}

The authors declare that they have no competing interests.

\section{Authors' contributions}

CB was involved in the original idea and carried out all measurements of gas exchange. HB participated in the design of the study, performed the statistical analysis and wrote together with CB the first draft. JPQ and JPF contributed significantly in the presentation of results and discussion. NF substantially contributed in the discussion. All authors read and approved the final manuscript.

\section{Acknowledgements}

During this work the corresponding author was supported by the National Science and Technology Commission (CONICYT) through the project FONDECYT 1090259 "Disturbance mediated water and nutrient stresses regulate carbon assimilation and allocation in sclerophyll ecosystems in Central Chile: A process-based approach". We thank Corporación Nacional Forestal for their support to carry out FONDECYT 1090259, and for providing accommodation and technical advice within the National Reserve "Roblería de los Cobres de Loncha". We also thank Mrs. Cristina Sáez N. (Universidad de Chile), Mr. Roberto Cerda R. (CONAF) and Mr. Eric Campos (Universidad de Chile) for their kind advice and valuable technical skills. The experiments and measurements undertaken for this paper comply with the current laws of Chile.

\section{Author details}

${ }^{1}$ Facultad de Ciencias Forestales y de la Conservación de la Naturaleza, Universidad de Chile, Casilla 9206, Santiago, Chile. ${ }^{2}$ Centro de Estudios de Zonas Áridas, Universidad de Chile, Casilla 129, Coquimbo, Chile. ${ }^{3}$ Facultad de Ciencias Agronómicas, Universidad de Chile, Casilla 1004, Santiago, Chile.

Received: 14 February 2014 Accepted: 18 June 2014

Published online: 16 August 2014

\section{References}

Armesto JJ, Arroyo MTK, Hinojosa LF (2007) The mediterranean environment of Central Chile. In: Veblen T, Young KR, Orme AR (eds) The physical geography of South America: 184-199. Oxford University Press, United State of America

Arroyo MTK, Marquet P, Marticorena C, Simonetti J, Cavieres LA, Squeo FA, Rozzi R (2004) Chilean winter rainfall - Valdivian forests. In: Mittermeier PRRA, Hoffmann M, Pilgrim J, Brooks T, Goettsch-Mittermeier C, Lamoreux J, Da Fonseca GAB (eds) Hotspots revisited: earth's biologically richest and most endangered terrestrial ecoregions: 99-103. CEMEX, Mexico

Baldocchi DD, Harley PC (1995) Scaling carbon dioxide and water vapour exchange from leaf to canopy in a deciduous forest: II model testing and application. Plant Cell and Environment 18:1157-1173

Benites J, Saintraint D, Morimoto YK (1994) Degradación de tierras y producción agrícola en Argentina, Bolivia, Brasil, Chile y Paraguay: Erosión de Suelos en América Latina. Oficina Regional de la FAO para América Latina y el Caribe, Santiago, pp 83-116

Bernacchi CJ, Elsingsaas CP, Portis AR, Long SP (2001) Improved temperature response functions for models of Rubisco-limited photosynthesis. Plant Cell Environ 24:253-259

Bernacchi CJ, Portis AR, Nakano H, Von Caemmerer S, Long SP (2002) Temperature response of mesophyll conductance. Implications for the determination of Rubisco enzyme kinetics and for limitations to photosynthesis in vivo. Plant Physiology 130:1992-1998

Brooks A, Farquhar GD (1985) Effect of temperature on the $\mathrm{CO}_{2} / \mathrm{O}_{2}$ specificity of ribulose-1, 5- bisphosphate carboxylase oxygenase and the rate of respiration in the light: estimates from gas-exchange measurements on spinach. Planta 165:397-406

Cabrera M (2002) Respuestas ecofisiológicas de plantas en ecosistemas de zonas con clima mediterráneo y ambientes de alta montaña. Rev Chil Hist Nat 75:625-637

CONAF (1999) Catastro y Evaluación de Recursos Vegetacionales Nativos de Chile. Proyecto CONAF-CONAMA-BIRF, Santiago, Chile, p 89

De Lucia EH, Whitehead D, Clearwater MJ (2003) The relative limitation of photosynthesis by mesophyll conductance in co-occurring species in a temperate rainforest dominated by the conifer Dacrydium cupressinum. Funct Plant Biol 30:1197-1204
Ethier GJ, Livingston NJ (2004) On the need to incorporate sensitivity to $\mathrm{CO}_{2}$ transfer conductance into the Farquhar-von Caemmerer-Berry leaf photosynthesis model. Plant, Cell and Environment 27:137-153

Ethier GJ, Livingston NJ, Harrison DL, Black TA, Moran JA (2006) Low stomatal and internal conductance to $\mathrm{CO}_{2}$ versus Rubisco deactivation as determinants of the photosynthetic decline of ageing evergreen leaves. Plant, Cell andEnvironment 29:2168-2184

Evans JR (1989) Photosynthesis and nitrogen relationships in leaves of $C_{3}$ plants. Oecologia 78:9-19

Farquhar GD, Sharkey TD (1982) Stomatal conductance and photosynthesis. Annual Review of Plant Physiology 33:317-345

Farquhar GD, von Caemmerer S, Berry JA (1980) A biochemical model of photosynthetic $\mathrm{CO}_{2}$ assimilation in leaves of C3 species. Planta 149:78-90

Field C, Mooney HA (1986) The photosynthesis - nitrogen relationship in wild plants. In: Givnish TJ (ed) The economy of plant form and function. Cambridge University Press, Cambridge, pp 25-55

Flexas J, Bota J, Loreto F, Cornic G, Sharkey TD (2004) Diffusive and metabolic limitations to photosynthesis under drought and salinity in C (3) plants. Plant Biol 6:269-279

Flexas J, Díaz-Espejo A, Galmés J, Kaldenhoff R, Medrano H, Ribas-Carbo M (2007) Rapid variations of mesophyll conductance in response to changes in $\mathrm{CO} 2$ concentration around leaves. Plant, Cell and Environment 30:1284-1298

Flexas J, Ribas-Carbo M, Diaz-Espejo A, Galmes J, Medrano H (2008) Mesophyll conductance to $\mathrm{CO}_{2}$ : current knowledge and future prospects. Plant Cell Environ 31:602-621

Flexas J, Barbour MM, Brendel O, Cabrera HM, Carriqui M, Diaz-Espejo A, Douthe C, Dreyer E, Ferrio JP, Gago J, Galle A, Galmes J, Kodama N, Medrano H, Niinemets U, Peguero-Pina JJ, Pou A, Ribas-Carbo M, Tomas M, Tosens T, Warren CR (2012) Mesophyll diffusion conductance to CO2: an unappreciated central player in photosynthesis. Plant Science 193:70-84, doi:10.1016/j. plantsci.2012.05.009

Gallé A, Flórez-Sarasa I, Aououad HE, Flexas J (2011) The Mediterranean evergreen Quercus ilex and the semi-deciduous Cistus albidus differ in their leaf gas exchange regulation and acclimation to repeated drought and re-watering cycles. J Exp Bot 62:5207-5216

Galmes J, Medrano H, Flexas J (2007) Photosynthetic limitations in response to water stress and recovery in Mediterranean plants with different growth forms. New Phytol 175:81-93

Genty B, Briantais JM, Baker NR (1989) The relationship between the quantum yield of photosynthetic electron-transport and quenching of chlorophyll fluorescence. Biochimica Et Biophysica Acta 990:87-92

Gotor B (2008) Evaluación de parámetros fisiológicos y de Crecimiento en plantas de Quillaja saponaria Mol. bajo condiciones de déficit hídrico: Memoria para optar al título de Ingeniero Forestal. Facultad de Ciencias Forestales, Universidad de Chile, Santiago, Chile

Grassi G, Magnani F (2005) Stomatal, mesophyll conductance and biochemical limitations to photosynthesis as affected by drought and leaf ontogeny in ash and oak trees. Plant Cell Environ 28:834-849

Grassi G, Meier P, Cromer R, Tompkins D, Jarvis PG (2002) Photosynthetic parameters in seedlings of Eucalyptus grandis as affected by rate of nitrogen supply. Plant Cell Environ 25:1677-1688

Griffin KL, Tissue DT, Turnbull MH, Whitehead D (2000) The onset of photosynthetic acclimation to elevated $\mathrm{CO}_{2}$ partial pressure in field-grown Pinus radiata D: Don. after 4 years. Plant Cell Environ 23:1089-1098

Gu L, Sun Y (2014) Artefactual responses of mesophyll conductance to CO2 and irradiance estimated with the variable $J$ and online isotope discrimination methods. Plant, Cell and Environment 37:1231-1249

Gulias J, Flexas J, Abadia A, Medrano H (2002) Photosynthetic responses to water deficit in six Mediterranean sclerophyll species: possible factors explaining the declining distribution of Rhamnus ludovici-salvatoris, an endemic Balearic species. Tree Physiol 22:687-697

Harley PC, Sharkey TD (1991) An improved model of $C_{3}$ photosynthesis at high $\mathrm{CO}_{2}$ - reversed $\mathrm{O}_{2}$ sensitivity explained by lack of glycerate reentry into the chloroplast. Photosynth Res 27(3):169-178

Harley PC, Loreto F, Di Marco G, Sharkey TD (1992) Theoretical considerations when estimating the mesophyll conductance to $\mathrm{CO} 2$ flux by analysis of the response of photosynthesis to $\mathrm{CO}_{2}$. Plant Physiol 98:1429-1436

Hassiotou F, Ludwig M, Renton M, Veneklaas EJ, Evans JR (2009) Influence of leaf dry mass per area, $\mathrm{CO}_{2}$ and irradiance on mesophyll conductance in sclerophylls. J Exp Bot 60:2303-2314 
Hogan KP, Whitehead D, Kallarackal J, Buwalda JG, Meekings J, Rogers GND (1996) Photosynthetic activity of leaves of Pinus radiata and Nothofagus fusca after 1 year of growth at elevated $\mathrm{CO}_{2}$. Aust J Plant Physiol 23(5):623-630

Jones HG (1992) Plants and microclimate: a quantitative approach to environmental physiology. Cambridge University Press, Cambridge, UK

Kellomaki S, Wang KY (1996) Photosynthetic responses to needle water potentials in Scots pine after a four-year exposure to elevated $\mathrm{CO}_{2}$ and temperature. Tree Physiol 16:765-772

Long SP, Bernacchi CJ (2003) Gas exchange measurements, what can they tell us about the underlying limitations to photosynthesis? procedures and sources of error. J Exp Bot 54:2393-2401

Loreto F, Harley PC, Di Marco G, Sharkey TD (1992) Estimation of mesophyll conductance to $\mathrm{CO}_{2}$ flux by three different methods. Plant Physiol 98:1437-1443

Manter DK, Kerrigan J (2004) A/C-i curve analysis across a range of woody plant species: influence of regression analysis parameters and mesophyll conductance. J Exp Bot 55:2581-2588

Mcmurtrie RE, Leuning R, Thomson WA, Wheeler AM (1992) A model of canopy photosynthesis and water use incorporating a mechanistic formulation of leaf $\mathrm{CO}_{2}$ exchange. For Ecol Manag 52:261-278

Montenegro G (1984) Atlas de anatomía de especies vegetales autóctonas de la Zona Central. Ediciones Universidad Católica de Chile, Santiago

Murray MB, Smith Rl, Friend A, Jarvis PG (2000) Effect of elevated $\mathrm{CO}_{2}$ and varying nutrient application rates on physiology and biomass accumulation of Sitka spruce (Picea sitchensis). Tree Physiol 20:421-434

Niinemets Ü, Díaz A, Flexas J, Galmés J, Warren R (2009a) Importance of mesophyll diffusion conductance in estimation of plant photosynthesis in the field. J Exp Bot 60:2271-2282

Niinemets Ü, Wright I, Evans J (2009b) Leaf mesophyll diffusion conductance in 35 Australian sclerophylls covering a broad range of foliage structural and physiological variation. Journal Experimental Botany 60:24333-22449

Peisker M, Apel $\mathrm{H}$ (2001) Inhibition by light of $\mathrm{CO}_{2}$ evolution from dark respiration: comparison of two gas exchange methods. Photosynth Res 70:291-298

Pena-Rojas K, Aranda X, Fleck I (2004) Stomatal limitation to $\mathrm{CO}_{2}$ assimilation and down-regulation of photosynthesis in Quercus ilex resprouts in response to slowly imposed drought. Tree Physiol 24(7):813-822, Schreiber U, W Bilger \& C Neubauer (1994) Chrorophyll fluorescence as a nonintrusive indicator for rapid assessment of in vivo photosynthesis. In: ED Schulze \& MM Caldwell (eds) Ecophysiology of photosynthesis: 49-70. Springer Verlag, Berlin

Pons TL, Flexas J, von Caemmerer S, Evans JR, Genty B, Ribas-Carbo M, Brugnoli E (2009) Estimating mesophyll conductance to $\mathrm{CO}_{2}$ : methodology, potential errors, and recommendations. J Exp Bot 60:2217-2234

Prioul JL, Chartier P (1977) Partitioning of transfer and carboxylation components of intracellular resistance to photosynthetic $\mathrm{CO}_{2}$ fixation: a critical analysis of the methods used. Ann Bot 4:789-800

R Core Team (2013) A language and environment for statistical computing. R Foundation for Statistical Computing, Vienna, Austria, URL http://www.Rproject.org/

Ripullone F, Grassi G, Lauteri M, Borghetti M (2003) Photosynthesis-nitrogen relationships: interpretation of different patterns between Pseudotsuga menziesii and Populus euroamericana in a mini-stand experiment. Tree Physiol 23:137-144

Sage RF, Pearcy RW (1987) The nitrogen use efficiency of $C_{3}$ and $C_{4}$ plants. Plant Physiol 84:959-963

Schreiber U, Bilger W, Neubauer C (1994) Chrorophyll fluorescence as a nonintrusive indicator for rapid assessment of in vivo photosynthesis. In: Schulze ED, Caldwell MM (eds) Ecophysiology of photosynthesis: 49-70. Springer Verlag, Berlin

Sharkey TD (1985) Photosynthesis in intact leaves of $C_{3}$ plants: physics, physiology and rate limitations. Bot Rev 51:54-105

Singsaas EL, Ort DR, Delucia EH (2004) Elevated $\mathrm{CO}_{2}$ effects on mesophyll conductance and its consequences for interpreting photosynthetic physiology. Plant Cell Environ 27:41-50

Takashima T, Hikosaka K, Hirose T (2004) Photosynthesis or persistence: nitrogen allocation in leaves of evergreen and deciduous Quercus species. Plant Cell Environ 27:1047-1054

Terashima I, Hanba YT, Tholen D, Niinemets Ü (2011) Leaf functional anatomy in relation to photosynthesis. Plant Physiol 155:108-116
Tholen D, Ethier G, Genty B, Pepin S, Zhu XG (2012) Variable mesophyll conductance revisited: theoretical background and experimental implications. Plant Cell Environ 35:2087-2103

Tomas M, Flexas J, Copolovici L, Galmes J, Hallik L, Medrano H, Ribas-Carbo M, Tosens T, Vislap V, Niinemets U (2013) Importance of leaf anatomy in determining mesophyll diffusion conductance to CO2 across species: quantitative limitations and scaling up by models. Journal of Experimental Botany 64(8):2269-2281, doi:10.1093/jxb/ert086

Tosens T, Niinemets Ü, Westoby M, Wright IJ (2012) Anatomical basis of variation in mesophyll resistance in eastern Australian sclerophylls: news of a long and winding path. J Exp Bot 63:5105-5119

Turnbull MH, Tissue DT, Griffin KL, Rogers GND, Whitehead D (1998) Photosynthetic acclimation to long-term exposure to elevated $\mathrm{CO}_{2}$ concentration in Pinus radiata D: Don. is related to age of needles. Plant Cell Environ 21:1019-1028

Turnbull MH, Murthy R, Griffin KL (2002) The relative impacts of daytime and night-time warming on photosynthetic capacity in Populus deltoides. Plant, Cell and Environment 25:1729-1737

von Caemmerer S (2000) Biochemical models of leaf photosynthesis. Victoria, Australia, CSIRO Publishing, Collingwood

von Caemmerer S, Evans JR (1991) Determination of the average partial pressure of $\mathrm{CO}_{2}$ in chloroplasts from leaves of several $\mathrm{C}_{3}$ plants. Aust J Plant Physiol 18:287-305

von Caemmerer S, Farquhar GD (1981) Some relationships between the biochemistry of photosynthesis and the gas exchange of leaves. Planta 153:376-387

Walcroft AS, Whitehead D, Silvester WB, Kelliher FM (1997) The response of photosynthetic model parameters to temperature and nitrogen concentration in Pinus radiata D. Don Plant, Cell \& Environment 20:1338-1348

Walker B, Ariza LS, Kaines S, Badger MR, Cousins AB (2013) Temperature response of in vivo Rubisco kinetics and mesophyll conductance in Arabidopsis thaliana: comparisons to Nicotiana tabacum. Plant Cell Environ 36:2108-2119

Warren CR (2004) The photosynthetic limitation posed by internal conductance to $\mathrm{CO}_{2}$ movement is increased by nutrient supply. J Exp Bot 55:2313-2321

Warren CR (2006) Why does photosynthesis decrease with needle age in Pinus pinaster? Trees 20:157-164

Warren CR, Adams MA (2002) Phosphorus affects growth and partitioning of nitrogen to Rubisco in Pinus pinaster. Tree Physiol 22:11-19

Warren CR, Adams MA (2006) Internal conductance does not scale with photosynthetic capacity: implications for carbon isotope discrimination and the economics of water and nitrogen use in photosynthesis. Plant Cell Environ 29:192-201

Warren CR, Ethier GJ, Livingston NJ, Grant NJ, Turpin DH, Harrison DL, Black TA (2003) Transfer conductance in second growth Douglas-fir (Pseudotsuga menziesii (Mirb.)Franco) canopies. Plant Cell Environ 26:1215-1227

Whitehead D, Walcroft AS, Griffin KL, Tissue DT, Turnbull MH, Engel VC, Brown K, Schuster WSF (2004) Scaling carbon uptake from leaves to canopies: insights from two forests with contrasting properties. In: Mencuccini JGM, Moncrieff J, McNaughton KG (eds) Forests at the land-atmosphere interface: 231-254. CAB International, U.K. CABI. http://arrow.uws.edu.au:8080/vital/access/manager/ Repository/uws:2660

Wullschleger SD (1993) Biochemical limitations to carbon assimilation in $C_{3}$ plants - a retrospective analysis of the $\mathrm{A} / \mathrm{Ci}$ curves from 109 species. J Exp Bot 44:907-920

\section{doi:10.1186/s40693-014-0008-0}

Cite this article as: Brito et al:: Mesophyll conductance constrains photosynthesis in three common sclerophyllous species in Central Chile. Revista Chilena de Historia Natural 2014 87:8. 